\title{
La etnología chiriguano de Alfred Métraux
}

\section{Federico Bossert y Diego Villar}

\section{OpenEdition}

\section{Journals}

Edición electrónica

URL: https://journals.openedition.org/jsa/6873

DOI: $10.4000 /$ jsa. 6873

ISSN: 1957-7842

Editor

Société des américanistes

\section{Edición impresa}

Fecha de publicación: 1 diciembre 2007

Paginación: 127-166

ISSN: 0037-9174

\section{Referencia electrónica}

Federico Bossert y Diego Villar, «La etnología chiriquano de Alfred Métraux», Journal de la Société des américanistes [En línea], 93-1 | 2007, Publicado el 15 junio 2012, consultado el 04 septiembre 2022. URL: http://journals.openedition.org/jsa/6873 ; DOl: https://doi.org/10.4000/jsa.6873 


\title{
LA ETNOLOGÍA CHIRIGUANO DE ALFRED MÉTRAUX
}

\author{
Federico BOSSERT * y Diego VILLAR **
}

\begin{abstract}
Este trabajo analiza la influencia de los maestros de Alfred Métraux, Marcel Mauss y Erland Nordenskiöld, en su formación académica, intelectual y profesional; y, en un sentido más general, el influjo teórico y metodológico de las ideas de la sociología francesa y la escuela de americanistas de Gotemburgo en la obra temprana del suizo, dedicada a la familia linguística tupí-guaraní en general y a los chiriguano y tupinambá en particular. Para ello se analizan sus escritos sobre la religión y el profetismo tupinambá; el proyecto pionero del Instituto de Etnología de Tucumán; el papel desempeñado por la ideología, los prejuicios de la época y la valoración estética en la recolección de objetos de cultura material; las peculiaridades del método de trabajo de campo de Métraux y su influencia en la relación con los chiriguano; la tesis de la alfarería chiriguano como elemento cristalizador de influencias culturales andinas, chaqueñas y amazónicas; $y$, finalmente, la relación significativa entre el simbolismo mítico y el universo femenino. [Palabras claves : Métraux, tupi-guaraní, tupinambá, chiriguano, chané.]
\end{abstract}

L'ethmologie chiriguano d'Alfired Métraux. Dans ce travail, nous analysons l'importance de Marcel Mauss et Erland Nordenskiöld, les maîtres d'Alfred Métraux, dans sa formation académique, intellectuelle et professionnelle. Dans un sens plus général, nous examinons la forte influence théorique et méthodologique des idées de la sociologie française et de l'école des américanistes de Göteborg dans les premières cuvres du Suisse, consacrées à la famille linguistique tupi-guarani en général et aux Chiriguano et Tupinamba en particulier. Pour ce faire, nous allons étudier les écrits de Métraux sur la religion et le prophétisme tupinamba, le projet pionnier de l'Institut d'ethnologie du Tucuman, le poids de l'idéologie et des préjugés de l'époque, la valorisation esthétique des objets de la culture matérielle, les particularités de la méthode du travail de terrain de Métraux et son influence dans sa relation avec les Chiriguano, la thèse sur la céramique chiriguano en tant qu'élément cristallisant les influences andines, du Chaco et amazoniennes, enfin, la relation entre le symbolisme mythique et l'univers féminin. [Mots clés : Métraux, Tupi-Guarani, Tupinamba, Chiriguano, Chané.]

\footnotetext{
- Universidad de Buenos Aires, Paraguay 419, Capital Federal Buenos Aires, Argentina (1057) [fbossert@gmail.com].

“ CONICET, Callao 555, Capital Federal Buenos Aires, Argentina (1022) [villardieg@gmail.com]. Journal de la Société des Américanistes, 2007, 93-1, pp. 127-166. O Société des Américanistes.
} 
The Chiriguano Ethmology of Alfred Métraux. The paper analyzes the influence of Erland Nordenskiöld and Marcel Mauss on the early academic, intellectual and professional career of Alfred Métraux. In a broader perspective it focuses on the theoretical and methodological influence of French sociology and the Scandinavian school of Americanist ethnology on Métraux's first researches on historical and living Tupi-Guarani groups, particularly the Tupinamba and Chiriguano. We pursue our analysis across diverse aspects of Métraux's work, including: his treatment of religion and prophetism among the Tupinamba; his participation in the pioneer project that created the Ethnology Institute in Tucuman; the manifestation of ideology, inherited prejudice and esthetic values in his gathering of material culture collections; the singularities of Métraux's fieldwork and its impact on his relationship with the Chiriguano; his thesis that Chiriguano pottery reflected particular mixtures of Andean, Chaco and Amazonian influences; and, finally, the significant link he found between mythic symbolism and the feminine universe. [Key words: Métraux, Tupi-Guarani, Tupinamba, Chiriguano, Chane.]

\section{INTRODUCCIÓN}

Un pionero de la etnología amerindia describía el itinerario intelectual de Alfred Métraux con estas palabras: «Iniciaron su carrera dos maestros que representan mentalidades bien diferentes: Marcel Mauss y Erland Nordenskiöld. Del discípulo de Durkheim, Métraux heredó el interés por el estudio comparativo de las religiones; del americanista sueco, las tendencias difusionistas y el amor al indio » (Baldus 1963, p. 45). El propósito de estas páginas consiste, justamente, en mostrar el peso relativo de esas influencias en la obra etnográfica temprana de Métraux. Por un lado, la familia tupí-guaraní en general y los chiriguano en particular ocuparon - junto con los tupinambá - el centro de la atención de Métraux durante su formación universitaria y los primeros años de su vida profesional. Por el otro, el análisis de la alfarería constituye una suerte de denominador común en sus escritos sobre los chiriguano y chané - y, por tanto, nos ofrece una excelente oportunidad para revisar buena parte de sus estudios sobre estos grupos.

Según el mismo Métraux, los chiriguano nacieron de una fusión entre, por un lado, grupos que originariamente pertenecían a la rama mojo-mbaure de la familia lingüística arawak y que habian migrado en una fecha temprana hasta instalarse en las laderas orientales de los Andes bolivianos y, por el otro, sus conquistadores de origen tupí-guarani que, a partir de finales del siglo Xv, llegaron a la zona desde las lejanas costas atlánticas. De la unión y el mestizaje entre ambas sociedades nació, al pie de los Andes y en la periferia occidental del Gran Chaco, el grupo que la literatura conoce como " chiriguano » (Métraux 1930a y 1948a; Susnik 1968; Braunstein 1978; Saignes 1990; Combès y Saignes 1994). Los guaraní aportaron ciertos aspectos religiosos, el ethos guerrero y 
fundamentalmente el idioma, y los arawak las jerarquías de estratificación social y ciertos aspectos de « cultura material » como las técnicas de riego, el tejido, las máscaras rituales y la alfarería. Pues bien, así como Métraux creyó descubrir en la cerámica chiriguano los rastros de ese lejano origen dual, guaraní y arawak, aquí rastrearemos en sus estudios sobre la alfarería los rastros de su doble formación profesional - en Suecia, bajo la influencia de Erland Nordenskiöld, y en Francia, como alumno de Marcel Mauss.

\section{Los DOS MAESTROS}

\section{Gotemburgo y Erland Nordenskiöld}

Entre 1925 y 1928, Métraux siguió los cursos de Mauss en París y de Nordenskiöld en Gotemburgo, donde redactó sus dos disertaciones de doctorado. En el museo etnográfico de esta última ciudad tuvo oportunidad de estudiar las vastas colecciones de cultura material de muchos de los grupos que poco tiempo después visitaría, entre ellos los chiriguano y los chané. Aquí nos interesa evaluar, justamente, en qué medida los estudios etnográficos, históricos e incluso las prenociones de Métraux acerca de los chiriguano provenían de la influencia de Nordenskiöld - de sus libros, pero sin dudas también de sus lecciones y conversaciones.

En 1901, la noticia de la muerte de su padre encuentra al joven Nordenskiöld dirigiendo la Expedición Sueca Chaco-Cordillera, entre Salta y el altiplano; en 1932, al norte de aquel sitio, Alfred Métraux (1932b, p. 233) recibe la noticia de la muerte de su maestro en Suecia:

Fue en la Quebrada del Toro, no lejos de Tastil, que me enteré de la muerte de Erland Nordenskiöld, quien fue para mí el más caro de los amigos y de los maestros. En el tren que me llevaba hacia las tierras altas, repetí la ruta seguida por él treinta años antes, cuando, apenas un joven, comenzaba a dedicarse a la ciencia. Cada una de las estaciones donde nos deteníamos y cuyo nombre evocaba alguna excavación de la misión sueca, era para mí como una evocación de su obra y de su vida tan plena y tan rica. (Fernández 2003, p. 19)

Métraux nunca llegó a redactar una noticia necrológica en la revista que dirigía entonces en Tucumán; en cambio, redactó la introducción a un artículo sobre el Museo Etnográfico de Gotemburgo, y a la obra de Nordenskiöld como director - el sueco, que habia llegado a leerlo, premonitoriamente lo consideraba su « necrológica » (Wassén 1932). Las emocionadas palabras de Métraux revelan el afecto y la admiración que sentía hacia " un maestro incomparable », « un conductor que nos llevaba hacia una meta común y que nos insuflaba un ardor extraño », " uno de los más grandes etnógrafos de todos los tiempos », cuya 
simpatía estaba puesta ante todo en los indígenas y en todo lo que condujera a su conocimiento y su respeto: los laboriosos y modestos trabajadores de campo más que los teóricos, los pequeños cronistas que convivieron con ellos antes que los viajeros célebres. Al final de esas páginas, Métraux (1932b, p. 237) escribió: " Para nosotros, que fuimos sus discípulos, queda el deber de continuar su tarea, no siguiendo estrechamente su método - algo que él mismo habría criticado sino en su espíritu, es decir, con su entusiasmo, su desinterés y su apasionada voluntad de salvar el recuerdo de una humanidad que desaparece ». Es preciso entonces decir algo sobre el « método » y el « espíritu » de Nordenskiöld; lo cual nos permitirá apreciar, más adelante, la magnitud de la deuda de Métraux.

Con toda justicia, Robert Lowie (1933, p. 161) considera a Nordenskiöld como el fundador de una " escuela escandinava de americanistas »; una escuela con una orientación y una metodología definidas pero con premisas muy poco dogmáticas: « el escrutinio del material documental », el « sobrio examen de la evidencia » y la « aproximación comprensiva a los nativos». Si bien a grandes rasgos podemos calificar el enfoque de Nordenskiöld como « difusionista 》 - en la medida en que su principal interés era indagar la difusión de elementos culturales para reconstruir el mapa étnico de América del Sur previo a la conquista -, resulta imprescindible aclarar que su enfoque se distanciaba sensiblemente del difusionismo inglés o alemán, y por varias razones.

En primer lugar, por una metodología más cautelosa y científica, inclinada hacia la inducción, que se negaba a imponer a los hechos cualquier esquema general diseñado de antemano - pensemos en la teoría del « monotésmo primitivo » del Padre Schmidt o las conjeturas pan-egipcias de Elliot Smith (Stocking 1995). En contraposición con esas ambiciosas reconstrucciones, las investigaciones de Nordenskiöld operaban de un modo que Lowie (1974, p. 314) denomina "atomístico »; es decir, examinando la distribución de elementos culturales aislados y no el movimiento de grandes « conjuntos » culturales. Su principal herramienta de análisis era la construcción de cuadros y mapas de distribución de esos elementos, destinados a cuantificar su presencia o ausencia en diversos grupos; estos mapas, al combinarse, permitían una variedad de inferencias en torno de orígenes comunes, contactos, separaciones, redes de comercio y alianza ${ }^{1}$.

En segundo lugar, su enfoque de ningún modo llegaba a los extremos dogmáticos de los teóricos de los Kulturkreise, según los cuales debía excluirse de antemano la posibilidad de un desarrollo independiente de las invenciones $-\mathrm{y}$, por tanto, la semejanza entre dos elementos encontrados en grupos distintos constituía una prueba casi segura de algún tipo de relación entre ambos, sin importar las distancias. Las hipótesis de Nordenskiöld, en este sentido, guardaban mayor afinidad con los escritos de Boas y sus discípulos americanos, mucho más cautelosos y especíicos, e inclinados a asumir las incertidumbres del método e intentar análisis contextuales. En este sentido, recordando nuevamente a Lowie 
(1974, p. 195), podríamos ubicar al sueco entre los autores difusionistas « moderados ", para quienes la capacidad inventiva de las sociedades no podía ser estipulada a priori ni menos aún elevada a principio axiomático, y para quienes las semejanzas sólo constituían una evidencia de préstamos sólo cuando pudiera probarse la existencia cierta de contactos culturales. Estas posiciones, así como un profundo humanismo que buscaba ante todo comprender a los indigenas americanos, acercaban a Nordenskiöld a un relativismo cultural que era extraño a la mayoría de los difusionistas europeos, y le imponían un interés casi obsesivo por cualquier fenómeno que probara la capacidad inventiva de los pueblos amerindios. Según Métraux (1932b, pp. 235-236), el interés de su maestro por las invenciones y descubrimientos de los indígenas sudamericanos provenía - más que de cualquier posición teórica - de su deseo por rehabilitar la imagen de estos pueblos: « Nada le agradaba más que constatar que una técnica evolucionada era familiar a cierta tribu indígena antes de la llegada de los blancos, y siempre fue con emoción que leía los elogios otorgados a la inteligencia de los indios de América " (ver también Salomon y Skar 1987, p. 24; Wassén 1990, p. 42; Alvarsson 1982, p. 15; Lowie 1933, p. 160).

Sin compartir, pues, la intransigencia de las reglas desarrolladas por Graebner para la identificación de afinidades y la fijación de cronologías (« semejanza formal» y «asociación accidental»), los estudios de Nordenskiöld seguían algunas reglas muy generales sobre los procesos de difusión, las cuales guiaron tanto sus propios trabajos como también los análisis de Métraux sobre los chiriguano y chané. Algunas normas se aplican a los procesos de imitación o aculturación; así, por ejemplo, si un grupo migra a un nuevo hábitat donde otro ya se encuentra instalado, probablemente imitará mucho de su cultura material, lo cual provocará una cierta homogeneidad entre ambos. Otras reglas atañen a los procesos de invención; afirman que un grupo de gran tamaño modificará su civilización más rápidamente que otro pequeño, ya que las ideas nuevas surgen más fácilmente cuantos más individuos haya. Otras se ocupan del proceso de préstamo cultural: los grupos con una civilización inferior imitarán a otros de civilización superior con mayor probabilidad de que suceda lo inverso ${ }^{2}$.

Ahora bien, el caso chiriguano presentaba un interés particular para este tipo de estudios. Por un lado, imponía inevitablemente a la investigación los típicos procesos de " difusión »: dispersión migratoria, préstamo cultural, imitación y aculturación. Por otro lado, resultaba clave en el debate sobre la relación entre las culturas andinas y las de tierras bajas; y, en particular, en la cuestión de cuál había sido la dirección original de las influencias y las corrientes migratorias - en otras palabras, la difusión de determinados elementos presentes en ambos ámbitos. Desafiando la opinión tradicional, que sostenía un sentido unidireccional de este flujo con origen en los Andes, Nordenskiöld había desarrollado la tesis de una difusión en ambos sentidos: un auténtico intercambio. Esto colocaba en el centro del argumento a aquellos grupos que habitaban la zona de «transición » 
- principalmente los chané, y por extensión los chiriguano (Salomon y Skar 1987, pp. 22-23). Como veremos, al adoptar parte del método de su maestro sueco, Métraux (1943a, p. 3; 1946a, p. 211) también heredaba de él un interés especial por estos grupos, y postularía que los mismos - tal vez debido a su elemento arawak, $\tan$ receptivo y tan propenso a la hibridez - funcionaron históricamente como auténticas etnias bisagra que debido a su complejidad originaria y a su ubicación geográfica operaron como propagadores regionales de influencias culturales entre los pueblos del Chaco y los grupos andinos ${ }^{3}$.

Nordenskiöld (1920, p. xii) se interesó por los chiriguano y los chané desde sus primeros viajes a América, y los visitó en repetidas oportunidades, conviviendo con ellos un total de cinco meses - una cifra nada despreciable para un viajero en los inicios del siglo xx. A ellos dedicó el segundo volumen de sus Comparative ethnographical studies, algún artículo histórico, y una extensa sección de su libro de viajes a través del Gran Chaco, que incluye sus notas de índole más estrictamente " etnográfica ». Como etnógrafo, Nordenskiöld hacía mucho más que observar y consignar los aspectos de la vida social directamente relacionados con los objetos que coleccionaba. Su sensibilidad, su observación y su intuición eran tan agudas que - parafraseando un famoso epigrama - no sería excesivo postular que toda la literatura etnológica posterior sobre los chiriguano es apenas una serie de notas al pie de las páginas de Indianerleben. Sin embargo, acaso debido a su entusiasmo inicial por la zoología, a una concepción de la ciencia más inclinada a los criterios cuantificables o a su pasión por las colecciones y la museografía, el principal objeto de sus análisis fue siempre la cultura material, y sólo su última e inconclusa obra, dedicada a los cuna, se ocupó específicamente de la religión y la cosmovisión indígenas (Salomon y Skar 1987, p. 28) ${ }^{4}$. El origen del vivo interés de Métraux por los tópicos religiosos y la mitología, pues, debe ser rastreado en otra parte.

\section{París y Marcel Mauss}

Durante la década de 1920, Métraux siguió el curso de sociología religiosa dictado por Marcel Mauss en la École pratique des Hautes Études, y asistió a las lecciones que éste dictaba en el Institut d'ethnologie dirigido por Paul Rivet (Krebs 2005, p. 3; Fournier 2005, p. 221). Los dos maestros franceses iban a desempeñar un importante papel en su vida académica de aquellos años: Rivet lo recomendaría para la dirección del Instituto de Tucumán, y Mauss dirigiría su tesis doctoral sobre los tupinambá. Sabemos que la relación entre maestro y alumno era estrecha; además de la Universidad y el Instituto, ambos se hallaban en contacto en el ámbito del Instituto Francés de Antropología - una sociedad de estudiosos en la cual Mauss cumplía las funciones de tesorero; e incluso, luego de la partida de Métraux hacia Argentina, mantuvieron una correspondencia más o menos fluida a lo largo de los años (por ejemplo, Fournier 2005, p. 294) 5 . 
Intentar resumir en pocas páginas el enfoque general de Mauss sería descabellado. Así pues, a la hora de rastrear su influencia en la obra de Métraux, vamos a considerarlo - contra la visión canónica - como un continuador fiel del método sociológico de su tío materno Émile Durkheim, y a mencionar sus ideas particulares sólo en la medida en que resulte necesario. Como se sabe, uno de los principales intereses de Mauss y la escuela del Année sociologique eran los estudios religiosos. No es imposible suponer que la duradera pasión de Métraux por esta temática proviniera de sus años de estudio en París - al menos en parte, puesto que fácilmente podrían invocarse también razones biográficas. En particular, podríamos argumentar que su formación en la École pratique contribuyó a su interés por la mitología indígena. En efecto, sabemos que entre 1924 y 1932 los cursos dictados por Mauss en esa institución estuvieron consagrados exclusivamente a los «ritos orales ». Entre 1924 y 1927, Mauss dictó cursos sobre los ritos orales australianos y, entre 1927 y 1929, sobre los ritos orales negativos y la mitología en ese mismo continente (Fournier 2005, pp. 220221) ${ }^{6}$.

Con todo, si bien es bastante sencillo identificar la influencia de Mauss en cuanto a las temáticas religiosas en general, no es tan fácil percibirla en un área de vital importancia para cualquier discípulo de la escuela sociológica francesa: las reglas del método. En este sentido, si bien el ascendiente de Mauss - debido justamente a su carácter múltiple y antidogmático - puede detectarse prácticamente en cualquier antropólogo francés de la época, Métraux jamás se mostró explícitamente como un partidario de los métodos de análisis de esa escuela - por más que en alguna ocasión declarara al « estudio sociológico » como meta ideal de la etnografía. Sin embargo, existe un capítulo de las enseñanzas metodológicas de Mauss que prestaba especial atención a aquellos fenómenos materiales y tecnológicos de la vida social que tanto interesarían a su alumno, y en el cual conviene entonces indagar. El Instituto de Etnología fue creado en 1925 con el objeto de apoyar, promover y organizar el estudio etnográfico en las colonias francesas. El mismo Mauss ofrecía una treintena de lecciones de «etnografía descriptiva » cada año, y los problemas allí tratados agotaban los que podía enfrentar un investigador en el campo: inspiradas en las Notes and Queries, abarcaban desde las técnicas para el registro de datos hasta el estudio de fenómenos "mentales» o "biosociológicos ». Mauss enfatizaba particularmente la necesidad imperiosa de recolectar con el mayor rigor posible los hechos sociales procedentes de las colonias, lo cual constituiría un corpus de material precioso para la etnología del futuro. Muy poco antes de su muerte, los apuntes de sus lecciones fueron reunidos y publicados en su Manuel d'ethnographie. Métraux asistió a estos cursos; y, años mas tarde, cuando deploraba el estado de la etnografía francesa incluyendo en sus quejas al mismo Rivet, esas lecciones constituían la excepción: « Dar de una tribu la imagen de su vida y no disecar su cuerpo. Presentar los engranajes funcionando y no desmontados y clasificados 
siguiendo reglas perfectamente arbitrarias y empíricas. Vea para eso el curso de Mauss » (carta de 1936 a Leiris, citado en Poitry 1996, p. 7). Pues bien, en las páginas del manual encontramos consejos que Métraux parece haber aplicado rigurosamente a la hora de estudiar la cerámica chiriguano y documentarla por medio de fotografías:

Para la observación de las téenicas es indispensable una absoluta precisión. La más pequeña herramienta debe ser nombrada y localizada: quién la maneja, dónde fue encontrada, cómo se sirve de ella, para qué sirve, o si su uso es general o especializado (por ejemplo, el empleo de un cuchillo). Será fotografiada en posición de empleo, lo mismo que el objeto sobre el que se aplica, y su producto. También hay que sacar fotografias que muestren los diferentes estadios de fabricación. (Mauss 1974b, p. 44)

Un vistazo a las fotografías sobre el proceso de elaboración de la cerámica deja suponer que las imágenes tomadas por Métraux no deben poco a estos consejos; sin embargo, no debemos pasar por alto que los mismos consisten en una simple aplicación del sentido común al trabajo de campo, y que ya habían sido puestos en práctica por muchas de las buenas etnografías de principios de siglo, anteriores a los cursos de Mauss. De hecho, muchas de las imágenes que ilustran los libros de viajes de Nordenskiöld retratan escenas domésticas y cotidianas, y en algunos casos incluso acompañan - como una película - los diversos « estadios » del proceso tecnológico ?.

En líneas generales, podemos afirmar que, en sus estudios tempranos sobre los grupos chaqueños, Métraux no veía en los objetos de la cultura material " hechos sociales » que resultara preciso integrar analíticamente en el sistema social total, sino más bien rastros que hablaban de otras sociedades o acaso de su pasado. En este sentido, como veremos, la posible deuda de Métraux hacia Durkheim y Mauss no atañe tanto al concepto de « sociedad » sino más bien al de « civilización » (Mauss 1974a).

En este punto no podemos perder de vista, por otra parte, la especialización geográfica de ambos maestros. Mientras que Nordenskiöld era uno de los principales sabios americanistas del mundo, Mauss no ofrecía más que una atención secundaria a Sudamérica. En una carta a este último, escrita desde la Isla de Pascua en 1934 - pocos años después del primer viaje al Chaco -, el propio Métraux destacaba esta división de sus influencias:

Debo decir que el recuerdo de sus cursos ha sido una guía preciosa [...]. También aqui su enseñanza cosechará frutos en el trabajo de campo [...]. Simplemente quería decirle que, en el otro extremo del mundo, pienso en usted con reconocimiento, y que soy conciente de haber tenido con usted la mejor introducción al estudio de esta civilización tan distinta de aquellas de América a las cuales me había habituado. (citado en Fournier 1994, p. 612) 
Las respectivas influencias de ambos maestros, pues, obedecian a criterios geográficos además de los temáticos: Nordenskiöld en América del Sur, Mauss en el Pacífico. De hecho, si Métraux llegó a sentirse tan a gusto en Estados Unidos - donde enseñó en 1938 y residió en forma más o menos permanente entre 1941 y 1950 -, debió ser en parte porque en la etnología de ese país veía confluir las dos tradiciones que lo habían formado: por un lado, el juicioso historicismo empirista de Boas, tan similar al de Nordenskiöld; por el otro, las ideas de la escuela durkheimiana, importadas a Chicago a través de Radcliffe-Brown y luego de autores como Fred Eggan o Lloyd Warner ${ }^{8}$.

\section{Las tesis tupi-guarani}

Luego de estudiar sociología religiosa con Mauss hasta 1927, Métraux viajó a Suecia en 1928 para asistir al curso de Nordenskiöld en la Universidad de Gotemburgo. Bajo la dirección del maestro francés, redactó la tesis titulada $\mathrm{La}$ religion des Tupinamba et ses rapports avec celle des autres tribus Tupi-Guarani; y, como discípulo de Nordenskiöld, redactó - casi al mismo tiempo y también en Gotemburgo - La civilisation matérielle des tribus Tupi-Guarani. Ambas obras se publicarian en París en 1928. Dado que constituyen su primera aproximación a los chiriguano, y sistematizan las ideas e hipótesis con las cuales llegó a realizar su primer trabajo de campo, conviene decir unas palabras sobre ellas.

Comencemos por La civilisation matérielle. Esta obra es el estudio comparado de la cultura material de todos los grupos tupí-guarani sobre los cuales existía documentación en aquel entonces; es decir, los objetos que éstos producen o han producido, agrupados en diversos conjuntos según su función. El objetivo general de la labor comparativa consistía en identificar los rasgos propios de una hipotética « civilización tupí-guaraní » originaria; ubicar el lugar de origen de la misma - el centro desde el cual esos rasgos se difundieron; para luego rastrear los movimientos migratorios que llevaron a esa difusión. El terreno considerado, pues, era buena parte de América del Sur, y los procesos estudiados abarcaban siglos. A lo largo de la obra, Métraux apela a un criterio estadístico para diferenciar lo que puede ser considerado propio y original de los tupi-guaraní (no usar flechas envenenadas, no usar máscaras, la ausencia de pipas, la hamaca de algodón, el mortero de madera) y lo que a su juicio puede deberse a una influencia foránea, cuyos orígenes identifica en cada caso. En cuanto a la zona de difusión de estos rasgos, se une a Nordenskiöld y niega el origen andino propuesto por Schmidt y por Krause, y propone en cambio una irradiación desde la zona en la cual estos rasgos aparecen con mayor densidad: el curso superior del Tapajoz o la cuenca del Xingú, la zona limitada por el Amazonas, el Paraguay, el Tocantins y el Madeira (Métraux 1928b, pp. 290-312).

Es preciso recordar que Métraux redactó ambas tesis antes de realizar cualquier trabajo de campo en las tierras bajas sudamericanas; por lo tanto, sus 
materiales fueron las fuentes escritas de cronistas y etnógrafos y, fundamentalmente, en el caso de La civilisation matérielle, las colecciones del Museo de Gotemburgo ${ }^{9}$. Dada la magnitud de los grupos considerados, sus obras de referencia para el caso de los chiriguano y chané eran más bien acotadas en comparación con las numerosas fuentes citadas para los antiguos tupinambá, o incluso con las que llegaría a examinar pocos años después para el mismo caso chiriguano. Se trataban de unas pocas obras de Nordenskiöld, algunas páginas de von Rosen, la etnografía del misionero franciscano Bernardino de Nino, la relación de Lizárraga y alguna carta de Chomé. Sin embargo, la atención prestada por Nordenskiöld a la cultura material de los chiriguano y los chané, tanto en sus obras publicadas como en las colecciones reunidas para su museo, los ubicaba en un lugar de privilegio para llevar a cabo el juego de las comparaciones. Por otra parte, el antecedente directo de esta obra es el volumen que el sueco dedicara a las influencias recíprocas entre los chiriguano y los chané, donde cataloga con todo detalle aquellos rasgos de la cultura material tupí-guaraní traídos por los chiriguano en su llegada al borde de los Andes (Nordenskiöld 1920). Por lo tanto, si bien los tupinambá constituyen la referencia primordial para cada grupo de elementos considerado en cada capítulo, los chiriguano aparecen como el grupo de comparación por excelencia - y en algunos casos, como el de los instrumentos de cocina, son el único grupo secundario mencionado. Como se comprenderá, la comparación entre las dos « naciones » resultaba siempre provechosa. En primer lugar, por la abundancia de sus fuentes históricas. Pero, fundamentalmente, porque a ojos de Métraux ambas sociedades se encontraban en los extremos del continuum de la «civilización tupí-guaraní ». Los tupinambá, en el centro, reunían sus rasgos esenciales; los chiriguano, proyectados a través de sus migraciones hacia los confines (culturales y geográficos) de esa civilización, ocupaban una zona absolutamente diferente de la originaria, y habían recibido la influencia de los otros dos grandes conjuntos culturales de Sudamérica: los grupos andinos y los arawak. A su vez, esta influencia añadía un interés muy especial al estudio de los chiriguano, ya que los arawak eran - incluso más que las culturas andinas - la "civilización » que Métraux más frecuentemente comparaba con los tupí-guaraní ${ }^{10}$.

Para apreciar lo ambicioso del trabajo de Métraux, debemos evitar dar por sentadas sus conclusiones. Si partimos de la idea dada de una "civilización tupí-guaraní » (cualquiera sea la vigencia actual de esta noción) ${ }^{11}$, el libro puede parecernos simplemente anecdótico. Su importancia se revela cuando comprendemos que no se trataba, simplemente, de comparar diversos grupos que hablaban el mismo idioma - y resultaban, por eso mismo, comparables -, sino de demostrar la existencia concreta en el tiempo y el espacio de un núcleo de civilización tupí-guaraní (en parte, eso que hoy se ha dado a llamar ethos). En otras palabras, la obra identificaba una serie de rasgos culturales básicos y compartidos por detrás de las variaciones que existían entre todos esos grupos. Se 
trata de un emprendimiento similar, si se quiere, a rastrear los elementos célticos o romanos en las culturas europeas actuales, y definir a partir de ellos sus características básicas. Así entendida, pues, la empresa no puede parecer poco ambiciosa - ni poco arriesgada.

Ahora bien, tanto los problemas investigados en esta obra como la metodología para resolverlos siguen de cerca los intereses y el método etno-geográfico de Nordenskiöld. De hecho, este volumen habría podido integrar sin problemas la serie de los Comparative ethnographical studies, que todavía en esa época Nordenskiöld escribía y editaba en Gotemburgo. Muchos mapas utilizados para representar la distribución de objetos y técnicas provienen de esos libros; e incluso la clasificación de las industrias consideradas - que estructura los capítulos del volumen - reproduce la utilizada por Nordenskiöld en más de un tomo de aquella serie $^{12}$.

Escrita y publicada prácticamente al mismo tiempo que la obra anterior, $L a$ religion des Tupinamba buscaba sistematizar todas las informaciones conocidas en aquel momento sobre la vida religiosa de esa nación. Más allá de concentrarse en un solo grupo, la tesis sigue el esquema comparativo de su contraparte: cada capítulo comienza reseñando la temática en cuestión a partir de los materiales tupinambá, para luego presentar sus variaciones en otros grupos tupí-guaraní. Aparentemente, la intención de Métraux habría sido poner a prueba, en el campo de la religión, las hipótesis planteadas por el estudio de la cultura material; no obstante, la escasez de informaciones sobre muchos de los grupos se lo impidió: « Así, me será imposible controlar los resultados de la investigación realizada en una obra anterior, en otro dominio, y determinar en qué medida la civilización material de una tribu está en correlación con su religión » (Métraux 1928b, p. 4). A su vez, esa carencia impuso a las comparaciones un carácter más monográfico y limitado; la misma elección de los tupinambá como principal objeto del estudio se debió de hecho a la abundancia de información. El objetivo, sin embargo, seguía siendo el mismo: « Este paralelismo constituye nuestro único criterio para juzgar si una creencia o un rito pertenecen al fondo común de la religión tupí-guaraní. [...] En general, encontramos que estas correspondencias son particularmente numerosas entre las tribus guaraní unidas por lazos históricos ciertos, o que pertenecen a la misma ola migratoria " (ibid.). Gracias al Indianerleben de Nordenskiöld, así, los chiriguano ocupan un sitial privilegiado en las páginas comparativas de La religion des Tupinamba - junto con los apapocúva y los tembé estudiados por Nimuendajú. De hecho, la última página de la obra está dedicada a los movimientos tumpaístas chiriguano, a los que pocos años después Métraux dedicaría un largo estudio.

Si La civilisation matérielle debe tanto a Nordenskiöld, podemos preguntarnos si acaso ocurre algo similar con respecto al influjo de Mauss. En principio, el tema escogido parece indicarlo. Sabemos, al menos, que fue Mauss quien le aconsejó a Métraux revisar los manuscritos inéditos de André Thevet en la 
Biblioteca Nacional de París, lo cual lo llevó al descubrimiento de un número de capítulos que habian pasado inadvertidos para los historiadores, y en particular aquellos dedicados a la antropofagia ritual - que constituiría el núcleo de la tesis. Si bien esta tesis se proponía sistematizar y exponer los materiales históricos, sus esbozos de análisis y el interés que traducen los temas elegidos responden, en líneas generales, al tratamiento que los autores del Année otorgaban a los fenómenos religiosos; por ejemplo, cuando enfatiza el carácter religioso de prácticas como las migraciones buscando su contraparte en ciertas creencias míticas, o bien cuando examina detenidamente los aspectos rituales de la antropofagia. Lo mismo podría decirse del orden de los capítulos, tras el cual subyace una división similar a la que estructura Les formes élémentaires de la vie religieuse - entre creencias religiosas (personajes míticos, mitología, dioses, genios de la selva, espíritus), prácticas religiosas (curaciones, ritos del ciclo vital, antropofagia) y fenómenos que pertenecen al siempre ambiguo conjunto de la « magia ». Por otro lado, ciertas expresiones puntuales remiten directamente a nociones de la escuela sociológica. Así, por ejemplo, se describen las fiestas de bebida en términos que podrían integrar la definición más ortodoxa de la efervescencia durkheimiana:

Los pintorescos cuadros que nos han trazado los antiguos cronistas de las escenas a las que daban lugar estas fiestas expresan bien la exaltación salvaje por la cual estaban poseídos estos indios por lo común tan tranquilos. No tiene nada de sorprendente que este estado fuera considerado por los tupinambá como una suerte de crisis mística colectiva, en la cual todos se elevaban de algún modo por encima de ellos mismos. (Métraux 1928b, p. 200)

Sin embargo, más allá de este tipo de planteos generales, y cuando la argumentación cede a formulaciones de carácter más teórico y apartadas de la descripción, la tesis parece recurrir a nociones ajenas a la corriente sociológica ${ }^{13}$. En este sentido, su confesión de haber buscado sin éxito rastros de totemismo entre los tupí-guaraní, así como la imputación de este fracaso a las lagunas que existian en las fuentes - que a primera vista parecen comentarios gratuitos -, pueden ser vistas como una justificación frente a las ambiciones de la escuela. En ese tiempo, al estudiar la religión de las sociedades « simples » o " primitivas » parecía casi forzoso descubrir alguna forma de totemismo; y esta ausencia de rastros, de no ser atemperada, podía interpretarse como una seria impugnación frente a las hipótesis fundamentales de Durkheim (1995, p. 5).

Para los cultores de la sociología durkheimiana, además, las metas y las unidades de análisis eran muchas veces distintas de las de Nordenskiöld. El principal objeto de la sociología eran los grupos individuales (las « sociedades »), con una existencia política definida, con miras a examinar su funcionamiento interno y el descubrimiento de las leyes que lo rigen. Sin embargo, Durkheim y Mauss no dejaron de tener en cuenta los fenómenos que interesaban a los difusionistas, a los cuales denominaron "fenómenos de civilización». A su 
juicio, la " civilización » - un concepto ciertamente más vago que el de « sociedad »-era el sistema de hechos que, si bien poseen una unidad y una identidad, no se limitan a una organización política determinada, sino que son por definición « internacionales », y por tanto susceptibles de ser compartidos por varias sociedades (Mauss 1974a, p. 453) ${ }^{14}$. Ejemplos de esto son los que propone, precisamente, la alfarería chiriguano: las técnicas y las artes.

En diversos artículos y reseñas sobre las obras del difusionismo, Mauss señaló las virtudes y limitaciones de esta escuela. Estas críticas, ante todo, abordan cuestiones metodológicas: dificultad para la elección de « rasgos característi$\cos$ », riesgo de las reconstrucciones hipotéticas, etc. Pero más allá de estos reparos, Mauss admitía la premisa de que los fenómenos de civilización constituyen una prueba de conexiones históricas y geográficas que pueden ser inferidas; así, aceptaba la utilidad de este tipo de estudios "históricos y geográficos » siempre y cuando desplegaran sus hipótesis con cierta cautela: «Modelos de estos estudios son los realizados por Nordenskiöld sobre América del Sur. Nosotros mismos hemos alentado, al mismo tiempo que él, los trabajos de Métraux sobre los elementos de la civilización de los tupis » (ibid., p. 461). Ahora bien, más allá de estos vagos elogios, no debemos olvidar que - por útiles que resulten - estos tipos de estudios no cubren las ambiciones ni los intereses del sociólogo. En las propias palabras de Durkheim y Mauss (1969, p. 685. Traducción nuestra):

Sin dudas, no habríamos pensado excluir la sociología de este tipo de investigaciones si no se creyera tan a menudo que explicar una civilización implica simplemente buscar de dónde viene, de quién ha sido tomada, por qué vía pasa de tal punto a tal otro. En realidad, el verdadero modo de explicarlas es descubrir las causas de las cuales resulta - es decir, cuáles son las interacciones colectivas, de diversos órdenes, que la han producido.

$\mathrm{El}$ « origen » de los fenómenos sociales, en otras palabras, es diferente de su " causa ».

Si bien la palabra « civilización » no pertenece - ni mucho menos - al acervo conceptual exclusivo de la escuela sociológica francesa, el uso que le da Métraux se acerca bastante al propuesto por Durkheim y Mauss. Explica, en efecto, que el propósito de su obra sea « definir la civilización común a todas las naciones que hablan guaraní », para lo cual tratará « la civilización de estos indigenas como si no formaran más que una sola y misma nación ". Así, se vuelve posible averiguar « si un elemento cultural es el bien común de todos los tupi-guaraní o si es un privilegio particular de sólo algunas tribus » (Métraux 1928a, p. 45) ${ }^{15}$.

Para terminar, ambas tesis conducían a Métraux hacia una misma conclusión respecto de los chiriguano. Como ocurría con otros grupos tupí-guaraní emigrados de la zona de difusión original y sometidos a la influencia de otras culturas, su civilización material y su vida religiosa habian sido profundamente transforma- 
das. Si bien toma de Nordenskiöld la expresión «tribu guaranizada » para referirse a los chané - reflejando la imposición absoluta de la lengua guaraní infligida por los conquistadores -, podría decirse que Métraux defendía la idea contraria - es decir, que veía a los chiriguano como un grupo tupí-guaraní profundamente « chaneizado » $\mathrm{o}$ " arawakizado ». Las palabras son contundentes: « Nordenskiöld ha dividido los elementos que pertenecen a la cultura primitiva de los chiriguano y los que, por intermedio de los chané, han sido recibidos de la región andina. Estos últimos son lo bastante numerosos como para que los chiriguano no tengan más de guaraní que la lengua y algunos objetos conservados por rutina » (ibid., p. 300) ${ }^{16}$.

\section{El estudio de los Chiriguano}

\section{Las colecciones y el trabajo de campo}

En 1929 Métraux (1953) llegó a la provincia de Tucumán, en Argentina, para ocupar el puesto de director del Instituto de Etnología de la universidad local, que incluía un pequeño museo. Sin dudas, cuando aceptó el cargo tenía en mente el ejemplo de Gotemburgo; no sólo en cuanto a la organización de las exposiciones, sino también como una meta ambiciosa, ya que los orígenes del museo sueco también habían sido modestos y fueron las exploraciones y gestiones de Nordenskiöld las que lo convirtieron en uno de los principales centros de etnografía sudamericana (Wassén 1932, pp. 238-239; 1990) ${ }^{17}$. Un museo de etnografía en Tucumán, por otro lado, contaba con una enorme ventaja comparativa: la cercanía con el « terreno », la fuente de los indios y los materiales. Y existía un beneficio ulterior: "Arqueológicamente, el Chaco es aún una terra incognita » (Métraux 1946a, p. 209). Los planes etnológicos del suizo para el Gran Chaco, en efecto, parecen haber sido sumamente ambiciosos; en pocos años esperaba convertirse en su mayor especialista y hacer de su museo el mayor centro de estudio especializado en esa región.

La práctica etnográfica temprana de Métraux, en estas circunstancias, se vio signada por la necesidad imperiosa de reunir colecciones que poblaran las salas del museo - aunque pronto necesitaría más salas para alojar las nutridas colecciones. Sin embargo, el verdadero motivo de esa premura era la consciencia de que la cultura material indígena desaparecía rápidamente, y que en veinte o treinta años ya no quedarían más que vestigios. En innumerables oportunidades, prácticamente cada vez que escribió sobre los indígenas del Chaco, Métraux deploró su situación - que consideraba desesperada -, así como la desaparición de sus culturas - que juzgaba inexorable. Sus escritos sobre los chiriguano están plagados de este tipo de denuncias. Las metáforas elegidas en ellas solían ser escatológicas; así, habla de "civilizaciones que mueren », de colecciones de 
mitos reunidas in extremis, de tradiciones (artísticas, mitológicas) que desaparecerían para siempre cuando murieran los últimos ancianos que las conocían: « La nación chiriguana está agonizando: esta raza valerosa que ha derrotado siempre a los conquistadores españoles y que hasta el siglo pasado se ha mantenido independiente, desaparece y se "barbariza" al contacto del blanco » (Métraux 1929a, p. 1; véase también 1929c; 1932a, p. 119). También, con frecuencia, señalaba a los agentes que consideraba responsables de esta lamentable situación. Ante esta percepción del campo, la etnografía y la reunión de colecciones devenían un « deber sagrado », y la responsabilidad de registrar el testimonio de culturas destinadas a desaparecer resultaba una carga tan angustiante como agobiante y agotadora. Años después, en una entrevista cercana a su suicidio, Métraux recordaría este contexto: « Uno de los grandes dolores de mi vida de hombre es haber asistido a la agonía de tantas de estas pequeñas sociedades [...] que en realidad guardan un valor profundo, y cuya desaparición ciertamente representa una pérdida muy grande » (citado en Bing 1964, p. 23$)^{18}$.

Ciertamente, la aculturación era un proceso que valía la pena estudiar, y con los años Métraux iba a convertirse en un especialista en este fenómeno. Resulta muy curiosa, en este sentido, la resistencia que manifestó en los primeros tiempos a ocuparse de los fenómenos de la aculturación chiriguano. Pocas veces los consideraba como hechos de "difusión »-por ejemplo, cuando trazaba una relación entre, por un lado, la « apertura cultural » de los chiriguano, su capacidad para incorporar elementos culturales del blanco, y por el otro su veloz aculturación y desaparición. Veía en la aculturación provocada por el contacto un proceso fundamentalmente homogenizador, cuyo resultado era una « masa amorfa » frente a la cual las consideraciones científicas o difusionistas debían ceder lugar al juicio moral que lamentaba una pérdida irreparable de la diversidad cultural. Métraux no ocultaba su repugnancia hacia esa especie de amalgama culturalmente amorfa que constituían los « mestizos », los « cholos », los « criollos », ni tampoco su desprecio y enemistad hacia los procesos de aculturación sufridos por los indígenas. Era imposible no comparar el estado de cosas que encontraba en el Chaco con el que describiera Nordenskiöld apenas dos décadas antes - que en el cotejo ganaba un estatuto casi idílico. La « decadencia » era, también, aquello que sus predecesores habían observado apenas unas décadas antes, y él ya no podía encontrar ${ }^{19}$.

No mucho tiempo después de su llegada a Tucumán, Métraux consiguió reunir los fondos para su primera expedición etnográfica, dirigida al grupo que conocía mejor debido a sus estudios monográficos sobre los tupí-guaraní: los chiriguano. En el prefacio de la monografía en la cual consignó los resultados de ese viaje, describe en detalle su itinerario. Partiendo de Tucumán, ingresó a Bolivia desde la montaña, atravesando la frontera en La Quiaca, y se dirigió a Tarija. Desde allí, viajando hacia el norte, alcanzó las « tolderías chiriguano » del 
alto Pilcomayo. Siguiendo hacia el noreste, atravesó las comunidades de Timboy e Itasiti hasta llegar a los poblados ubicados en la confluencia del Pilcomayo y el Salado; y luego desde ahí, en la misma dirección, llegó hasta Cuevo. Prosiguió en línea recta hacia el norte, atravesando el Parapetí, visitando todas las comunidades del valle de Caipipendi hasta alcanzar Charagua. Éste fue el límite septentrional de su viaje; desde allí descendió hacia el sur, pasando por Masavi, y dedicando las últimas semanas a las comunidades chané del norte argentino. Su experiencia entre los chiriguano y chané, pues, abarcó casi todas las variedades étnicas de estos grupos - de hecho, sólo le faltó visitar las comunidades izoceñas del árido bajo Parapetí (Métraux 1930a, pp. 295-296, 391).

Acaso por tratarse de su primer expedición "científica ", Métraux parecía guardar un grato recuerdo de este viaje. El resumen de cuentas había sido exitoso; se habían reunido vastas colecciones de objetos (unas 200 piezas de cerámica) y mitos; en las misiones los frailes franciscanos lo habían recibido afectuosamente e incluso lo habían asistido en sus investigaciones. Sin embargo, también hubo contratiempos: en muchas de las comunidades descubrió que la mayor parte de los hombres adultos había marchado a trabajar en la construcción de un camino, y por lo tanto enfrentó la resistencia y la opacidad de las mujeres, que no se mostraban demasiado comunicativas mientras sus maridos estaban ausentes. Esta incómoda situación, sumada a su desconocimiento del idioma, restringió su rango de observaciones, y como veremos le impuso una perspectiva analítica particular.

\section{El problema de la cerámica chiriguano y chané}

Publicado en la revista del Instituto en 1930, «Études sur la civilisation des indiens Chiriguano » puede ser considerado la summa chiriguano de Alfred Métraux. A diferencia de sus dos tesis, se trataba de una monografía etnográfica basada en una investigación de campo directa y dedicada a un único grupo. Conviene revisar entonces qué tipo de problemas guían las casi doscientas páginas de este trabajo, qué tipo de hipótesis propone, y qué métodos utiliza. Podría pensarse que, por tratarse del estudio de una sola sociedad, sería posible detectar con mayor claridad las enseñanzas de la escuela sociológica. Pues bien, la respuesta a estas cuestiones es siempre una y la ofrece el mismo Métraux, cuando en las primeras páginas se declara seguidor de las pesquisas de Eric von Rosen y Erland Nordenskiöld. Resulta significativo que los « Études... » se compongan de una única primera parte, dedicada exclusivamente a la civilización material; en efecto, su principal objeto son las enormes colecciones reunidas, cuyos elementos son descritos en detalle e ilustrados en abundancia por medio de múltiples fotografías y dibujos. La cultura material estructura y domina entonces un trabajo cuya profundidad sociológica se limita a indicaciones sobre la existencia social de los objetos. 
No puede sorprendernos que Métraux haya puesto tanta atención en la alfarería, ni que en "Études... » dedique a la cerámica el capítulo más extenso e incluya fotografías tan numerosas. Si una de las metas de la etnografía, tal como había aprendido a practicarla en Suecia, consistía en unir el presente con el pasado, la cerámica ocupaba necesariamente un lugar privilegiado entre sus objetos de estudio. En efecto, al plasmar en forma objetiva y verificable tradiciones estéticas, se trataba de uno de los principales criterios a la hora de reconocer " culturas » arqueológicas o " civilizaciones » etnográficas, así como también a la hora de trazar relaciones entre ambas. La cerámica es una industria que, a diferencia de otras, no se encuentra tan limitada por su función; permite un amplio espectro de variaciones morfológicas y decorativas y da lugar a verdaderos "estilos » culturales. Nordenskiöld había observado ya que aquellos elementos culturales que no se encuentran directamente influidos por el ambiente y la necesidad de supervivencia, como los juegos de azar o las manifestaciones artísticas, constituían la mejor referencia para el estudio de las migraciones; su carácter más o menos « libre » o " gratuito » los convertía en una cifra privilegiada de la difusión y el contacto. Este hecho fue aprovechado por Métraux (1928a, p. 238; 1948b, p. 73) desde temprano, quien escribía en La civilisation matérielle: «Para el caso de la cerámica, poseemos preciosos puntos de referencia que permiten decidir si una vasija es o no de procedencia guaraní ». Esos criterios de referencia son fundamentalmente la forma y los motivos decorativos - aunque también pueden considerarse los procesos de confección. Es así que «Études... » dedica buena parte de sus páginas sobre esta industria a la clasificación y el análisis de las formas y las decoraciones, procurando identificar, en cada caso, las influencias visibles.

Los dos principales antecedentes de este estudio fueron los trabajos de Félix Outes y, una vez más, Nordenskiöld. Outes (1909) había publicado, veinte años antes, una breve monografía sobre el tema. Sobre la base de una colección reunida en Bolivia, ensayó una tipología agrupando las piezas según su creciente complejidad. Su ensayo no contenía mucho más que esta clasificación de formas y tipos de decoración, puesto que el autor no había realizado un estudio en el terreno y sólo disponía de las notas dispersas que existen en las crónicas. Por su parte, Nordenskiöld (1920, pp. 138-146) dedicó a la cerámica chiriguano todo un capítulo de su volumen sobre la cultura material de los chiriguano y chané, en el cual no es difícil descubrir - al menos en forma seminal - muchas de las ideas e hipótesis que Métraux desarrollaría luego. Su principal interés, por supuesto, era identificar las diversas influencias que desembocaron en la alfarería chiriguano - ante todo las andinas, que presuntamente habían llegado a los chiriguano por medio de los chané. Este último influjo podía inferirse a partir de la forma de ciertas vasijas, o de la presencia de asas o agarraderas en algunos ejemplares. Incluso era posible identificar una influencia de las culturas chaqueñas en la 
cerámica chané, plasmada en la práctica - contraria al uso normal - de pintar las piezas luego de haberlas cocido.

En La civilisation matérielle, Métraux se había ocupado de la cerámica chiriguano " a la distancia ", en su conjunto, como un término de comparaciones muy amplias, y limitándose a reproducir las conclusiones de Nordenskiöld. Dentro del conjunto tupí-guaraní, la « evolución » de esta industria era presentada como un proceso análogo al experimentado por la cerámica omagua - que también había sufrido influencias andinas - y también en contraposición con la « decadencia » de las cerámicas de los guarayo y pauserna. Tras la investigación en el terreno, el enfoque de « Études... » cambió su escala; pasó a ser concentrado, minucioso, a explotar al máximo las ventajas que el etnógrafo posee sobre el arqueólogo. Es así que comienza describiendo largamente todos los procesos técnicos que requiere la confección de la cerámica. El resto del capítulo se dedica a precisar, por medio de pormenorizadas comparaciones, la influencia andina.

La tesis de la influencia andina era de larga data. Debenedetti (1910) había asociado esta cerámica con ciertas piezas de alfarería halladas hacia el suroeste, en la Quebrada de Humahuaca; Nordenskiöld y Boman apoyarían luego esta idea, a la cual añadieron evidencias históricas suplementarias. En respaldo de esta idea, por ejemplo, Nordenskiöld (1920, p. 143) mencionaba el sugestivo hecho de que « la palabra chiriguana para el cántaro de agua es $i r u$, lo cual posee una fuerte reminiscencia con el nombre quichua yuru dado al mismo tipo de cántaro ». Métraux estimaba que los ejemplares reunidos por él no sólo confirmaban definitivamente esta relación, sino que incluso permitían precisarla. La influencia andina no pudo llegar directamente desde las culturas de Humahuaca, al menos no a todo el territorio chiriguano - por ejemplo, no a la zona del alto Pilcomayo; todo indicaba que el verdadero origen " andino » había sido la cultura chicha, cuyo territorio se extendía al norte de Humahuaca y cuya cerámica revelaba las semejanzas más visibles con la chiriguano y chané. Existian, por otro lado, evidencias históricas del sometimiento de comunidades chicha a los chiriguano, que las obligaban a pagar tributo y bien pudieron tomar a sus mujeres como esposas - tal como, efectivamente, ocurrió con las mujeres chané. Todo apuntaba, pues, a una conclusión definitoria: « Creo que no es correcto hablar, a propósito de los chiriguano, de cultura andina o incaica. El primero de estos términos es demasiado vago y el segundo parcialmente falso. En este capítulo he buscado demostrar que la cerámica chiriguano ofrece estrechas afinidades con aquella de las civilizaciones que, por numerosos puntos de contacto, parecen haber sufrido una influencia chicha o atacama y que han precedido la cultura de los inca » (Métraux 1930a, p. 427).

Enfrascadas en este contexto de discusión, las páginas comparativas de "Études... » procuraban discernir las influencias culturales amalgamadas en la cerámica. Outes había pasado por alto un importante rasgo que observaría Nordenskiöld y luego profundizaría Métraux: la dualidad estilística. En efecto, 
se constataba la existencia de dos tipos de cerámica: la primera dedicada a las tareas cotidianas, la segunda a ocasiones más bien extraordinarias. Outes desconfiaba de las referencias al respecto, sosteniendo que los ejemplares que examinó de « vasos de uso diario » poseían los mismos ornamentos que los otros (no hace falta decir que resolver esta cuestión sin haber observado in situ los usos sociales de la cerámica resultaba por lo menos arriesgado). En opinión de Métraux, la dualidad de estilos de la cerámica chiriguano no podía atribuirse a sus distintos usos. Luego de un minucioso análisis de su colección, ejemplar por ejemplar, decidió que confirmaba una semejanza entre el estilo de los vasos de uso cotidiano y la alfarería guaraní del Paraguay y la costa brasilera; en cambio, la cerámica decorada acusaba una influencia andina. La explicación del dualismo estilístico, pues, no era sólo funcional, sino ante todo histórica. Los arawak de la región, antes de ser invadidos, poseían una cerámica muy influenciada por las culturas andinas; luego, cuando sus mujeres pasaron a ser esposas de los conquistadores tupí-guaraní, enseñaron estas técnicas a sus hijas; mientras tanto, las mujeres tupí-guaraní incorporaron a la naciente sociedad chiriguano su tradicional cerámica, mucho más tosca: «El origen mixto de la cultura chiriguano se refleja en los dos tipos de recipientes de barro. Los cacharros básicos para cocina y las grandes tinajas de chicha, que no difieren de los recipientes similares de los guarani paraguayos, se adornaban con impresiones dactilares. Los utensilios de lujo, tipológicamente relacionados con los recipientes de la arqueología del sur de Bolivia y el norte argentino, se decoraban con modelos característicamente andinos " (Métraux 1948a, pp. 475-476; 1930a, pp. 396-428; 1929a). Una vez más, encontramos en Nordenskiöld (1920, p. 146) el antecedente directo de esta idea:

Es especialmente la finamente pintada cerámica la que, tanto en forma como en ornamentos, recuerda la cerámica de la zona cultural del oeste. Los sencillos potes de cocina, adornados con impresiones digitales, semejan más bien lo que se encuentra en el viejo territorio guaraní de Misiones [...]. Creo que la explicación sería que, cuando los chiriguano conquistaron las tierras que ahora ocupan, sus propias mujeres generalmente, o siempre, hacían trabajos con adornos de impresiones digitales. Como sabemos, los inmigrantes chiriguano tomaron cantidades de mujeres, presumiblemente de los chané en la mayor parte, pero probablemente también de otras tribus. Las mujeres raptadas de lugares vecinos al viejo reino inca eran, sin dudas, habilidosas ceramistas, y luego enseñaron su arte a sus hijas. Es esto lo que ahora continúa en su cerámica más fina, especialmente en las vasijas usadas para las grandes reuniones de bebida.

El hecho de que el tercer componente necesario, la influencia arawak, sea apenas perceptible en la forma de ciertas compoteras o vasos de tres cuerpos comunicantes, indica que los chané se hallaban en el territorio desde mucho tiempo antes, y que ya habían asimilado las técnicas alfareras andinas cuando sus conquistadores llegaron desde el naciente. 
La influencia andina, pues, quedaba demostrada con bastante precisión. Restaba analizar el supuesto parentesco entre la cerámica chiriguano y ciertas culturas arqueológicas halladas muy al sur de su territorio. Uno de los temas discutidos por Nordenskiöld había sido el origen étnico de los enterramientos en urnas; $y$ esta cuestión, en el caso chiriguano, resultaba crucial a la hora de definir su antigüedad en la región y los límites de su territorio. En efecto, durante la expedición sueca Chaco-Cordillera, Eric Boman $(1905,1908)$ había hallado urnas funerarias en Jujuy y en el valle de Lerma (Salta). Las clasificó como guaraní, concluyendo que el territorio chiriguano llegaba mucho más al sur que lo anteriormente supuesto. Esto dio lugar a una cierta polémica, en la cual intervinieron entre otros Nordenskiöld, Debenedetti y Outes. Nordenskiöld (2002, p. 225) apoyó la tesis de Boman, y Debenedetti incluso atribuyó a los chiriguano ciertos pasadores labiales (tembeta) hallados mucho más al sur todavía ${ }^{20}$.

La cuestión de fondo era en qué caso las semejanzas formales probaban la existencia de una identidad cultural, o al menos de contactos. Podemos considerar la cautelosa posición de Métraux como un episodio importante en sus estudios sobre la alfarería. Ya en La civilisation matérielle había establecido que no existía un tipo uniforme o característico de enterramiento tupí-guaraní, pues en general las costumbres funerarias son un elemento sometido a fuertes variaciones regionales; por lo tanto, « resulta muy arriesgado pretender deducir de la analogía entre ritos funerarios un parentesco de raza o contactos prolongados » (Métraux 1928a, p. 176). Por otro lado, y tal como había mostrado Nordenskiöld, el enterramiento en urnas no era una costumbre exclusiva de los pueblos guaraní (César 1966). Las excavaciones realizadas por Métraux en La Candelaria - una zona cercana a donde Boman había hallado las urnas de la discordia identificaron una cultura que también enterraba a sus muertos en vasijas, pero que no guardaba ninguna otra relación con los grupos tupí-guaraní. Con esta misma cautela Métraux (1934, p. 188; 1930b, p. 404) relativizó la validez de las pruebas aportadas por Debenedetti (1917): «Si bastara un tembetá o adorno labial para establecer la existencia de un movimiento o de un substrato étnico, el mundo entero sería guaraní ».

Ahora bien, en la cerámica chiriguano no sólo podía leerse el origen híbrido de esta civilización, sino también - como en un espejo oracular - su inevitable futuro. La progresiva « decadencia » de la cerámica tradicional por el contacto con el blanco ocurría principalmente de dos modos. En primer lugar, por el reemplazo de los materiales, la adopción de trastos de metal (y luego de plástico) en reemplazo de las piezas de cerámica, que derivaba directamente en la desaparición de la industria y la ausencia de mujeres artesanas en algunas comunidades (Métraux 1930a, p. 393). Esto implicaba, en algunos casos, la amarga certidumbre de haber comprado los últimos ejemplares que existían: « Partes y nos dejas sin vasijas ", le decían las ancianas chiriguano al despedirse (ibid., p. 396). En 
segundo lugar, la decadencia se debía al comercio de estas piezas, que imponía ajustar su confección a las exigencias del mercado, las cuales no beneficiaban en absoluto el mantenimiento de los viejos patrones - así, la repetición mecánica de motivos realizados con descuido era una respuesta a la " gran demanda » comercial de cerámicas, y la figuración de toscos rostros humanos en las vasijas « delata el deseo de satisfacer la brutal puerilidad de los turistas » (ibid., p. 390). Cuando de arte indígena se trataba, Métraux era más tradicionalista que los propios nativos: no consideraba a la influencia del blanco en la cerámica chiriguano como algo digno de estudio, y apenas daba lugar al lamento. Incluso no dudaba en confesar que no había querido reproducir en sus publicaciones « ... algunos vasos de mis colecciones [...] en razón de su forma completamente europeizada » (ibid., p. 388). En esta perspectiva, la conclusión inexorable era tan desesperada como temeraria: «Sin pretender pasar por profeta, creo poder asignar cinco años de vida a la alfarería artística de los chiriguano $»\left(\right.$ ibid., p. 396) ${ }^{21}$.

Si Métraux deploraba de tal modo esta « degeneración » se debe, como hemos dicho, a que consideraba a la tradicional cerámica chiriguano como una expresión artística exquisita. También aquí se oponía a la opinión de Outes (1909, pp. 134-135), quien negaba a esta industria cualquier propósito estético y le atribuía una morfología que apenas imitaba el mundo vegetal y un fin meramente funcional. Para Métraux y Nordenskiöld, en cambio, esta cerámica no sólo escapaba a las limitaciones impuestas por el uso, sino que también evadía en cierta medida la repetición de patrones tradicionales; ofrecía, en otros términos, un campo libre para las variaciones y las creaciones individuales. Ambos destacaban, pues, la existencia de verdaderos " estilos » o " escuelas » regionales: « Cada región, y a menudo cada poblado, posee su estilo particular, e incluso éste varía siguiendo la fantasía o la habilidad de cada ceramista » (Métraux 1930a, p. 390) ${ }^{22}$. Métraux llegaba así a distinguir tres «zonas» estilísticas: el alto Pilcomayo, el valle de Igüembe, y la zona meridional del territorio (Ivo, Macharetí y los chané del río Itiyuro). Incluso alcanzaba a discernir en las piezas la elusiva diferencia entre los chiriguano y los chané: « Las mujeres chané poseen un gusto más puro y muestran una mayor seguridad que las alfareras chiriguano. Puede verse que estas últimas no son más que sus alumnas » (ibid., pp. 390-391). En resumen, la cerámica no era esclava de la tradición, ni estaba sujeta a la repetición eterna de motivos y formas; su carácter homogéneo se debía más bien a lo que se llamaría « buen gusto » o « estilo ».

En el caso del arte indígena en general, y en particular respecto de la cerámica chiriguano, Métraux mostraba cierta resistencia a ceder ante el relativismo cultural. En este sentido, es revelador que otorgase una meta «artística » o " estética » a la exposición de esas piezas de cerámica en el museo de Tucumán, capaces de " sugerir modelos » a los visitantes occidentales, o su reiterada atribución de « buen gusto » a las mujeres chiriguano (Métraux 1929b, p. 2) ${ }^{23}$. Estos calificativos no parecen traducir - como en otras expresiones típicas de Métraux 
en aquella época - resabios evolucionistas, sino más bien una concepción del arte cercana a la que defendía el movimiento surrealista, del cual participó activamente. En efecto, a fines de la década de 1920 existió un acercamiento entre la naciente etnología parisina y los círculos artísticos surrealistas: se organizaban grandes exposiciones de arte indígena, algunos jóvenes antropólogos frecuentaban asiduamente los sitios de encuentro de la vanguardia literaria, veían la luz publicaciones - como Documents de Bataille - que combinaban tópicos etnológicos y artísticos (Fournier 2005; Giobellina Brumana 2005). En una entrevista realizada muchos años después, Métraux recordaba esos tiempos de exaltación surrealista hacia las «artes exóticas» como «la época en que me volví etnógrafo », " el momento en que sentí despertar mi vocación » (citado en Bing 1974 , p. 21). No es temerario, pues, advertir alguna huella de aquellos años de bohemia en sus juicios estéticos sobre los chiriguano.

\section{La educación sentimental}

Es conocida la expresión que Métraux usó para evocar la atracción que sentía por las comunidades indígenas: «nostalgia del Neolítico ». Pese a que menciona a los kayapó como ejemplo de sociedades "neolíticas », los rasgos que ofrece para caracterizarlos se aplican fácilmente a los chiriguano: grupos sedentarios, que practican la agricultura, organizados en pequeñas comunidades, sin poder centralizado - rasgos que, por otra parte, diferencian en buena medida a los chiriguano de los otros grupos chaqueños, de hábitos y nómadas y más dados a la caza y la recolección antes que a la agricultura. Por otro lado, esa «nostalgia » que según Métraux lo empujaba fatalmente a la etnografía no es de ningún modo la elaboración romántica de un hombre que observa su vida a la distancia y fantasea; no se trata tan sólo de una utopía puramente intelectual, sino también de una caracterización patética y precisa de ciertos estados de ánimo que lo asaltaban en el campo (Métraux 1978). Si la humanidad « ha hecho mal en ir más allá del neolítico » no es tan sólo por las razones que podríamos llamar rousseaunianas - la aparición de jerarquías, la multiplicación de injusticias - sino por razones más íntimas, relativas al tipo de existencia indígena que Métraux entrevió en sus primeros trabajos de campo, y cuya experiencia acaso le recordase alguna página de Durkheim sobre las relaciones entre la cohesión social y el suicidio: al hallarse la existencia « más integrada », " ofrece - en el plano psíquico, ya que no materialmente - una seguridad infinitamente superior a la que sentimos en nuestra propia civilización ", y « el hombre está infinitamente menos aislado que en Occidente » (citado en Bing 1964, p. 22) ${ }^{24}$.

Ahora bien, todo indica que Métraux sintió esa afinidad muy intensamente entre los chiriguano. Dado que en más de un escrito estableció claramente sus preferencias personales, sabemos que ni en los pueblos chaqueños ni en los andinos la relación entre indígenas y etnólogo fue tan fluida, respetuosa y 
distendida. Si su favor estaba claramente puesto en los « indios puros » frente a los mestizos y criollos que inexorablemente los reemplazaban, también era clara su preferencia por los chiriguano frente al resto de los grupos chaqueños. No escatimaba elogios hacia los chiriguano. Alababa su « rapidez de espíritu », su " curiosidad insaciable », su « ingenio », su « sentido de imitación » y su " prodigiosa memoria ». Además de estas cualidades intelectuales, destacaba otras virtudes psicológicas y morales como su «prodigioso orgullo nacional », su « innata cortesía », su honradez y su buen humor. Si a esto se añade la crianza amorosa de los niños y la ternura en las relaciones conyugales, el cuadro resulta poco menos que idílico (Métraux 1931a, pp. 93, 96, 98, 104-105; 1935, p. 423) ${ }^{25}$. La apología era aún más elocuente cuando se trataba de las mujeres: «Pocas indias me han causado una impresión tan favorable como las chiriguano. Cuando jóvenes, son por lo general muy bonitas, aun desde el punto de vista europeo. Su cutis es un tanto moreno, la nariz a veces derecha y fina, el cuerpo bien proporcionado y las piernas admirables ». Los elogios se acumulaban, y las muchachas chiriguano eran calificadas como « elegantes» y "coquetas », sus peinados como "meticulosos», y sus características personales eran el «buen gusto innato », la « intuición », la « sobriedad », la " prodigiosa paciencia », la « destreza » y la « asombrosa rapidez para aprender » (Métraux 1935, p. 417).

El corolario es que los chiriguano y los chané eran « dos tribus que cultural y lingüísticamente tienen poco o nada en común con los pueblos chaqueños » (Métraux 1946a, p. 197). La tesis encubre diversos tipos de prejuicios y prenociones. Lo curioso es que, en el fondo, las dos cualidades en que Métraux solía basar esta escala jerárquica eran la higiene personal y la moral sexual. Ahora bien, todo invita a pensar que, así como muchas de las temáticas indagadas por él provenían de su formación sueca, estas prenociones teñidas de evolucionismo, con sus consecuentes sentimientos de afinidad y simpatía, tenían - al menos en parte - un origen similar. En efecto, acerca de la higiene chiriguano había escrito von Rosen (1924, p. 224):

Con la posible excepción de los chané - una tribu en el mismo nivel cultural que ellos los chiriguano parecen ser un pueblo considerablemente superior a las tribus vecinas que habitan las regiones montañosas o el Gran Chaco. Tanto los indios montañeses como los chaqueños son sucios, mientras que los chiriguano por el contrario cuidan celosamente la limpieza corporal.

Nordenskiöld (2002, p. 139) expresaba una opinión similar: « Los chané y los chiriguano son muy limpios. Comienzan el día tomando un baño y luego se lavan varias veces por día ». El sueco incluso contraponía esa pulcritud con la suciedad de los chorote y mataco, sugiriendo una explicación causal de este contraste higiénico mediante una tesis no demasiado convincente, que apelaba a causas climáticas, estratos culturales diversos y procedencias de difusión migratoria (ibid.). También en cuanto a la moral sexual la vindicación de los chiriguano 
aparejaba la crítica del resto de los chaqueños. Métraux defendió la « decencia » del tipoy - el tradicional vestido de las mujeres chiriguano - tanto como el pudor; la castidad, « la pureza sexual » de sus portadoras y el « amor matrimonial » de sus uniones (Métraux 1935, pp. 424-425). Una vez más, la opinión encuentra antecedentes inmediatos en von Rosen (1924, p. 224), quien había contrapuesto esta castidad con la promiscuidad de las muchachas chorote; y en Nordenskiöld (2002, p. 208), quien escribió que « las mujeres chanés y chiriguanas son mucho más púdicas que las choroti o ashluslay ».

En segundo lugar, si la preferencia valorativa, afectiva y casi empática por los chiriguano frente a los pueblos chaqueños puede imputarse a una tradición intelectual colectiva, lo mismo puede decirse con respecto a la traducción de esos juicios de valor en argumentos etnológicos, los cuales propugnaban la mayor complejidad cultural de los chiriguano-y, en definitiva, justificaban comparativamente la superioridad de su civilización. En esta tesis intervenían nociones de corte evolucionista que, explícitas o no, colocaban a los pueblos agricultores por encima de los cazadores-recolectores en las escalas progresivas de desarrollo y complejidad. Métraux (1931a, p. 90) afirma respecto de los chiriguano:

En forma alguna debe considerarse a estos indios como los representantes de una tribu primitiva o salvaje. Su antigua cultura ya los coloca bastante arriba en la escala de las civilizaciones: son hombres que tienen una agricultura bastante desarrollada, una espléndida cerámica y estaban a punto de llegar al conocimiento de la metalurgia bajo la influencia de la región andina. ${ }^{26}$

Como era de esperar, encontramos la misma idea en la obra de los americanistas escandinavos: von Rosen (ibid.) escribe que « también en lo que respecta a la cultura material, los chiriguano y los chané están en un plano más alto que sus vecinos contemporáneos» y Nordenskiöld (ibid., p. 139) opina que, con su « cultura superior » los chiriguano « están en un nivel mucho más alto que los "salvajes" del Chaco » ${ }^{27}$.

\section{Migraciones y profetas}

Los chiriguano, en definitiva, constituían un caso excepcional para la aplicación y evaluación de los métodos heredados de la escuela etnológica escandinava: «Para quien desea verificar experimentalmente, por así decirlo, el valor de los métodos que salen a la luz en la etnografía moderna, para quien desea juzgar los factores que condicionan la formación de la evolución de las civilizaciones, no hay mejor campo de estudio que los indios chiriguano » (Métraux 1930a, p. 299). La razón más fuerte consistía en la existencia de crónicas históricas sobre el grupo desde prácticamente la fecha de nacimiento de la sociedad chiriguano, en su vinculación con sus « socios » chané; estas fuentes, en efecto, permiten conocer con bastante precisión la época de ese surgimiento, el origen de sus componentes, 
los grupos con quienes los chiriguano estaban en contacto, el carácter de esos vínculos, las influencias a las que se sometieron: «En una palabra, podemos asistir a la formación y al desarrollo de este pueblo desde su origen hasta su decadencia actual; experiencia única en América del Sur, acaso rara en otras partes y, en todo caso, rica en enseñanzas » (ibid.) ${ }^{28}$. En otras palabras, los hechos que en la mayoría de los casos era preciso reconstruir (la historia, la procedencia, la filiación cultural, las migraciones, los contactos) aquí se presentaban en buena medida « a la vista »; podían documentarse no a través de inferencias hipotéticas, sino a través de las crónicas. La documentación histórica permitía llenar las lagunas y resolver aquellos enigmas que en la gran mayoría de grupos se sumían en la opacidad y en la incertidumbre ${ }^{29}$. La nutrida etnohistoria chiriguano estaba llamada a verificar y comprobar las hipótesis que surgían al comparar dos conjuntos de datos: por un lado, la vida social en comunidades indígenas actuales; por el otro, los grandes procesos inferidos de los mapas de difusión:

El etnógrafo se siente tanto más cómodo en su análisis cuando a cada paso la historia confirma o invalida las constataciones a las cuales le conduce su trabajo comparativo. Camina entonces sobre una piso seguro, y los resultados a los que llegue en este dominio particular justificarán su método cuando lo emplee para resolver los problemas cuyos hechos conocidos sean menos completos. (ibid., p. 300) ${ }^{30}$

La abundancia de fuentes permitía, además, que las argumentaciones y los debates sobre el pasado abandonaran el dominio arqueológico y tuvieran lugar, directamente, en el campo de la historia. Ahora bien, en los estudios de Métraux sobre historia chiriguano puede descubrirse, una vez más, la doble influencia de su formación. Si bien retomaba las problemáticas directamente de Nordenskiöld, al mismo tiempo profundizaba un inédito interés por la dimensión religiosa, y sus trabajos sobre las migraciones tupí-guaraní constituyen el mejor ejemplo.

En un principio, Métraux adhirió a la vieja tesis de Nordenskiöld (1917), que veía en la expedición de pillaje planeada y liderada por el portugués Alejo García la primera migración guaraní hacia los Andes; en ese caso, detectaba su principal motivación en el saqueo, la atracción provocada por las riquezas incaicas ${ }^{31}$. Poco después iba a modificar su opinión, tanto sobre la época de la llegada guaraní como respecto de los verdaderos motivos de la migración. En cuanto a la primera cuestión, todo giraba en torno de una remota afirmación de Garcilaso, según la cual el inca Yupanqui - que reinó unos cien años antes de la incursión de García había hecho la guerra a los chiriguano; si esta afirmación resultaba exacta, entonces la presencia tupí-guaraní en la zona se remontaba a mucho tiempo antes que lo supuesto por Nordenskiöld, quien entendía que Garcilaso había confundido los períodos y en realidad refería hechos muy posteriores. Métraux (1948a), por una vez, pasó a disentir con su maestro; a su juicio, podían identificarse siete oleadas migratorias de los guaraní a través del Chaco, y la primera se remontaba 
hasta la década de 1470. En cuanto a la segunda cuestión, si bien Métraux encontraba la principal razón de las migraciones en la atracción ejercida por el imperio incaico - el deseo de pillaje o de comercio, clásicas razones de la lógica difusionista -, al mismo tiempo les atribuía una causa religiosa: el mito de la « tierra sin mal ». Se trataba del destino de aquellos que han muerto de acuerdo con las reglas del arte bélico, en el que los hombres viven por siempre jóvenes y gozan de una existencia sin esfuerzo. Para dar coherencia a esta combinación de causas, Métraux (1928b, pp. 201-224; 1930a, pp. 304-309; 1948a, p. 466) acentuaba entre las características de ese paraíso terrenal la abundancia de metales preciosos y tejidos, y sostenía que los chiriguano lo asimilaron al imperio incaico, al cual aplicaban el mismo nombre: kandire.

Esta indagación de las viejas utopías tupí-guaraní guió otra serie de trabajos históricos dedicados al milenarismo profético de los chiriguano (Métraux 1957). Durante la expedición de 1929, debido a ciertas sospechas de las autoridades, Métraux se vio forzado a detenerse algunos días en Tarija, y aprovechó la ocasión para revisar los manuscritos del Colegio Franciscano. Entre ellos figuraba el original de la obra que el Padre Mingo de la Concepción dedicó a la historia de ese Colegio. Métraux tuvo el privilegio de examinar el único manuscrito de la versión ampliada de la obra de Mingo fechado en 1795 (el « borrador » que luego fuera publicado data de 1791), misteriosamente extraviado sólo unos pocos años más tarde (ver Saignes 1984). La lectura del pasaje referente a las agitaciones lideradas por los tumpa chiriguano, que tuvieron lugar a fines del siglo XVIII, lo llevó a escribir acerca del profetismo. Podría pensarse que, por tratarse de un fenómeno que involucra las dimensiones religiosas de la organización social, cuya comprensión se busca en « los mitos y las creencias que la provocaron indirectamente », se encontrarán allí aplicadas al menos algunas nociones fundamentales de la escuela sociológica francesa. Pero no es así. Por un lado, el tratamiento comparativo del fenómeno, que lo vincula con hechos similares procedentes de Amazonía y Andes, no se dirige a definir rasgos formales comunes - como haría un seguidor de las reglas del método sociológico -, sino más bien a identificar su filiación étnica (Métraux 1931c, p. 81). Por otro lado, el único esquema teórico que se menciona en este artículo, y con el cual la argumentación dialoga, son las clásicas ideas de Frazer sobre la deificación de magos y reyes. Métraux encuentra, en el caso de los profetas chiriguanos, un desarrollo, una rectificación, y en líneas generales una verificación de esas ideas ${ }^{32}$.

\section{Mujeres y mitos}

Métraux pretendía escribir una continuación de su « Études... » que analizara la « civilización no-material » de los chiriguano - anunciada por el título « primera parte » y las palabras finales « a seguir ». Nunca lo hizo. Si bien en 1932 afirmaba que en la campaña chiriguano había puesto énfasis en el « elemento 
espiritual y psicológico » - es decir en la reunión de « mitos, cuentos » y « observaciones sobre la vida religiosa y espiritual de los indios »-parece probable que, antes de emprender la redacción de esa segunda parte, deseara realizar una investigación de campo distinta de aquel peregrinaje por la chiriguanía que le había impuesto la urgente necesidad de reunir colecciones (Métraux 1932c). Lo cierto es que abandonó muy pronto Tucumán y sólo regresó al Chaco en excursiones breves. Podemos considerar, sin embargo, que sus escritos posteriores sobre el grupo cumplieron, aunque en forma parcial y fragmentaria, aquella misión. Aquí vamos a considerar dos de las temáticas que abordó en ellos, y que guardan una interesante relación con el arte de la cerámica: por un lado, el lugar de las mujeres en la sociedad chiriguano, y por el otro la mitología.

Como hemos dicho, en muchas de las comunidades que Métraux visitó durante su viaje los hombres adultos habían partido. Esto le impuso concentrar sus observaciones en las mujeres, que iban a inspirar la primera temática. En algún trabajo más general sobre «la posición de la mujer en las sociedades primitivas ", Métraux (1931b; 1932d; 1935) había examinado el tema de los descubrimientos y el desarrollo de las industrias, y entre ellas la cerámica. Repetía así viejos esquemas de Bachofen, Morgan y el Padre Schmidt - la secuencia según la cual la mujer, que durante el estadio de caza y recolección se especializaba en la segunda actividad, se vio llevada a descubrir la agricultura, lo que aparejó el imprescindible sedentarismo; y luego, al quedar a cargo de la cocción de los vegetales, desarrolló el arte culinario, que derivó en la invención de los enseres de cocina, entre ellos la alfarería; lo cual, en palabras del propio Métraux (1931b, p. 124), « abrió vastos horizontes a otra actividad humana: el arte ». Fueron sin dudas sus impresiones acerca de las alfareras chiriguano las que lo llevaron a repetir esa idea grandilocuente. El carácter más conservador de las mujeres indígenas, en contraposición con los hombres - hecho sobre el cual había insistido ya Nordenskiöld -, ganaba en estas páginas una valoración psicológica general:

Es así que, entre los chiriguanos del Chaco, que son los últimos en América que siguen teniendo una cerámica propia y original, ésta es exclusivamente una manifestación del genio de la mujer que sola, en medio de la decadencia, ha sabido conservar el buen gusto y la habilidad [...] Muchos psicólogos han negado a la mujer dotes artísticos, considerándola a este respecto como inferior al hombre, pero en el caso de las tribus americanas es justamente la mujer que representa el sujeto creador en el arte. (Métraux 1931b, p. 125)

La ausencia de hombres adultos en las comunidades, sin embargo, no impedía una actividad que interesaba vivamente a Métraux: la recolección de mitos, realizada principalmente a través de informantes ancianos. En efecto, siempre prestó especial atención a la compilación de relatos, y durante la década de 1930 publicó diversos trabajos sobre la mitología de los grupos chaqueños (Métraux 
1946b). Pues bien, cuando visitó las comunidades chiriguano, en 1929, encontró - además de mujeres - ancianos que le relataron una cierta cantidad de mitos. El trabajo más importante donde expone algunos de ellos analiza, en términos ampliamente comparativos, una serie de variaciones sobre el mito de los mellizos - del cual, por otra parte, ya se había ocupado largamente en su tesis sobre los tupinambá (Métraux 1932a). La importancia de este trabajo no puede ponerse en duda, y el mismo Lévi-Strauss (1992, p. 80) llegó a calificar el mito registrado por Métraux como un « auténtico Génesis amerindio ».

En Métraux, la recolección y el estudio de la mitología guardan grandes similitudes con la reunión, la clasificación y el análisis de colecciones de objetos materiales. No era la primera vez que el lenguaje era tratado de este modo por la antropología americanista. Si bien el principal aporte de Nordenskiöld para el estudio de la mitología chiriguano y chané eran los propios mitos registrados en el campo, su peculiar tratamiento del lenguaje puede mencionarse como un interesante antecedente de estos estudios. Por citar el caso más notable, el sueco dedicó una obra a comparar los nombres que, en una variedad de grupos, recibieron ciertos objetos provenientes del contacto con el blanco: aves de corral, caballos, vacas, armas de fuego, frutas, tijeras, cuchillos, agujas y anzuelos. El objeto de la obra era inferir, a partir de las similitudes y variaciones entre esas palabras, las redes de contactos y migraciones que existieron entre los grupos. El cotejo de estas listas con los conocimientos históricos acerca del lugar y la época de la introducción de cada objeto permitiría entonces identificar los contactos, las vías de transmisión que existían de tribu en tribu, que en algunos casos llegaban a recorrer grandes distancias. Al recibir un nuevo elemento cultural de sus vecinos, el grupo solía adoptar la palabra para identificarlo: « $\mathrm{Al}$ rastrear la distribución de ciertas palabras post-coloniales, entonces, deberemos poder - tal como se mostrará - rastrear las rutas de los indios en tiempos del Descubrimiento, o poco tiempo después, así como las rutas seguidas por las grandes migraciones post-coloniales » (Nordenskiöld 1922, p. viii). Se trataba, pues, de una aplicación de su método etno-geográfico al campo de la lingüística; en efecto, las reglas aplicadas eran exactamente las mismas utilizadas para estudiar la distribución de objetos materiales ${ }^{33}$. En el caso de los chiriguano, este estudio confirmaba aquello que las fuentes históricas permitían suponer: su estrecha filiación con los distritos guaraní cercanos al río Paraná, y su migración desde esa zona en la tercera década del siglo xvi. En efecto, los chiriguano utilizaban los mismos nombres que los guaraní del Paraguay para los objetos introducidos por el blanco inmediatamente después de la Conquista (ibid., pp. 143-144).

El tratamiento casi museográfico que daba Nordenskiöld a las nuevas palabras indígenas echa luz sobre la forma en que Métraux emprendió el estudio de otro tipo de tradiciones orales: la mitología. En efecto, este último escribió sobre el tema páginas ampliamente comparativas, e invariablemente se mostró interesado por las semejanzas que percibía entre mitos de regiones muy lejanas. Ya en 
su estudio sobre los tupinambá, tanto la composición de los corpus míticos como las variaciones de un mismo relato eran concebidas como evidencias de relaciones culturales, como la cristalización de influencias y migraciones. En el estudio sobre mitología chiriguano, el interés continuó siendo aislar las vías de influencia por medio de las cuales un mito o un motivo mítico podía haber llegado hasta donde se lo encontraba. Quedaba descartada una «invención paralela », pues en Métraux son todavía los hombres quienes piensan los mitos - y no sólo los piensan, sino que también los transmiten e intercambian. Para facilitar las comparaciones, descomponía las versiones del mito en « temas », " motivos » o « episodios », y luego perseguía sus transformaciones en otras versiones provenientes de diferentes grupos. Así, cada episodio presente en las versiones chiriguano posee una marca de origen que permite reconstruir el camino que ha recorrido. Finalmente, se servía de mapas para identificar el « área de difusión » del mito. Así como su análisis de la cultura material le había permitido abstraer los rasgos que sustentaban el tipo ideal de la " civilización tupí-guaraní », este estudio, reconstruyendo las vías de difusión y siguiendo las huellas de las variaciones y las transformaciones, permitía conjeturar la « forma original y primitiva » del mito: " Solamente con trabajos de la índole del que trato de llevar a cabo aquí, llegaremos a poder caracterizar con toda seguridad la mitología propia de cada grupo lingüístico y podremos establecer el itinerario que han seguido ciertos motivos » (Métraux 1932a, p. 134) ${ }^{34}$.

Las conclusiones de estos estudios confirmaban y complementaban a las anteriores. La uniformidad mitológica tupí-guaraní se correspondía con una « unidad de cultura » entre los tupinambá, los guaraní del Paraguay y los tembé (Métraux 1928b, p. 29). Y, más importante aún, la mitología chiriguano se oponía a la del resto de los grupos tupí-guaraní: por un lado, no presentaba « dioses civilizadores » comparables a los personajes míticos tupinambá; por el otro, dejaba las acciones legendarias en manos de personajes animales como la dupla del armadillo y el zorro (Aguara-tumpa y Tatu-tumpa). Esta variación en las tradiciones orales, como si se tratara de una nueva técnica de alfarería, sólo podía explicarse por la acción de una influencia externa: fue una vez más el contacto con las creencias mitológicas chané, a su vez de origen arawak o andino, lo que llevó a los chiriguano a « animalizar » los dioses civilizadores (Métraux 1928b, pp. 2729; 1932a, p. 124). Esta influencia externa también se traducía en el episodio de la " rebelión de los objetos », presente en alguna versión chiriguano, que Métraux comparaba con mitos recogidos en Huarochiri, y consideraba por lo tanto un préstamo andino. Ahora bien, en este punto Métraux pasaba, en el mismo trabajo y sin mayores reparos, de los mitos a la cerámica. Por un lado, ambos dominios de la creación cultural eran igualmente válidos a la hora de rastrear contactos e influencias, debido justamente a que compartían el mencionado carácter « libre » y capaz de revelar orígenes muy lejanos. Por el otro, la cerámica constituía la mejor y más palpable evidencia de las conexiones que Métraux 
intentaba trazar en el campo de la mitología; en este sentido, el arte alfarero jamás dejó de constituir un respaldo sólido y confiable donde cimentar sus conclusiones.

\section{Palabras finales}

Si realmente llegó hasta aquí, el lector dispone ya de suficientes elementos como para juzgar en su conjunto los esfuerzos que Alfred Métraux dedicó a los chiriguano y chané. Hemos revisado los principales problemas que abordó y la metodología que utilizaba; $y$, en la medida de lo posible, hemos identificado los pesos respectivos en sus antecedentes e influencias. Vimos a un joven Métraux que intentó seguir, en América, los pasos de su maestro sueco, y que jamás dejó de ver a los chiriguano desde esa perspectiva. La misma elección de los temas de estudio hizo que la influencia de Mauss, si bien presente y perceptible, fuera opacada por la obra y las enseñanzas de Nordenskiöld. Por otro lado, la naturaleza de los grupos chaqueños - que tal vez frustraba las expectativas « sociológicas » de Métraux -, lo empujaba a esta elección. En 1933, luego de una expedición al Chaco, escribía a Lowie sobre la organización social chaqueña: "Sobre este último punto las investigaciones son muy difíciles en Sudamérica. Todo es amorfo y decadente $\gg{ }^{35}$. Es cierto que en varios pasajes de sus escritos tempranos encontramos referencias directas - aunque aisladas y no del todo relevantes - a las enseñanzas de Mauss y la escuela sociológica. Pero en ningún caso, y ni siquiera cuando el tema lo requería, los análisis de Métraux se encolumnaron dogmáticamente tras las teorías de esa tradición académica. Así, su estudio sobre el suicidio wichí se acerca mucho más al tratamiento dado por Malinowski (1926) en Crime and custom... que a la célebre tesis de Durkheim. El suicidio es presentado como un medio tradicional para canalizar la agresión mientras la vida en las misiones impide a los indígenas otros medios catárticos como las borracheras colectivas, las partidas de hockey o la guerra - la autoinmolación sirve, además, para satisfacer metas concientes de los individuos: venganzas y favores amorosos (Métraux 1943b).

La práctica etnográfica « de salvataje », como hemos dicho, era defendida e impulsada por sus dos maestros. Ambos, en fin, situaban las obras por encima de los hombres, privilegiaban el lento y modesto trabajo de equipo, atesoraban la recolección y el escrutinio de los datos brutos. La obra etnográfica de Métraux, durante sus años al frente del Instituto de Etnología de Tucumán, rindió homenaje a esos buenos ideales. Pero al elegir la acumulación de informaciones y desdeñar cualquier aventura teórica, Métraux se alistaba en el linaje de Nordenskiöld, pues, según sus propias palabras, al maestro escandinavo « le gustaba hablar de la caducidad de su obra teórica, y se consolaba pensando que sus libros de viajes permanecerían como documentos sobre un mundo desaparecido " 
(Métraux 1932b, p. 234). Como etnógrafo, Métraux siempre se mantuvo fiel a esta idea: su principal tarea, su ideal de trascendencia consistía en preservar un testimonio fidedigno de esas sociedades que desaparecían - en palabras de LéviStrauss (1964, p. 7), « contra las fantasías a veces peligrosas de los estetas y los teóricos ${ }^{36}$. En este sentido, resulta significativo que, cerca del final de su vida, Métraux (citado en Bing 1964, p. 23) otorgara ese solo mérito a su obra y su carrera: « Creo que esta idea, realmente fundamental, ha inspirado mi carrera de etnógrafo: he querido conservar el recuerdo, o la imagen, de estas pequeñas civilizaciones [que] van a morir, sin dudas ya están muriendo ». *

* Manuscrit reçu en novembre 2006, accepté pour publication en janvier 2007.

\section{Notas}

Agradecemos a Edgardo Krebs, Sarah Fee, Mónica Ferraro, Isabelle Combès, Philippe Erikson y al personal de la biblioteca del Museo Etnográfico de Buenos Aires por su disposición constante y su cálida y paciente colaboración.

1. Así, por ejemplo, en su estudio sobre los choroti y ashluslay, el objetivo trazado era determinar la procedencia de las "influencias culturales " para descubrir desde qué regiones habian llegado originalmente; el método consistía en señalar, en los mapas de América del Sur, la distribución geográfica de un gran número de " elementos de cultura " característicos de ambos grupos: armas, ornamentos, vestidos, utensilios, técnicas, etc. (Nordenskiöld 1929).

2. «Cuando un elemento de cultura se encuentra distribuido de tal suerte que se encuentra en una tribu de orden elevado al mismo tiempo que entre las tribus inferiores que la rodean, mientras que falta en otros territorios más extensos, siempre he admitido que por lo común éste ha llegado a la tribu menos civilizada debido a la intromisión de otra que lo es más » (Nordenskiöld 1929, p. 25). Así, el sueco supone que muchos de los elementos que sólo se encuentran en los grupos chaqueños y en los más occidentales grupos de origen amazónico (chiriguano y chané) deben haber tenido origen en estos últimos. Aquí encontramos, sin dudas, resabios evolucionistas. Pero, por un lado, sería preciso aclarar que las expresiones « superior » e " inferior » no poseian en Nordenskiöld una carga valorativa, sino que referian únicamente a la complejidad tecnológica - y referida a criterios cuantitativos y mensurables antes que a juicios de valor o a capacidades intelectuales. Es preciso observar que la misma idea de estos procesos supone sociedades en constante cambio e influencia mutua, cuyo éxito se mide en términos de adaptación al ambiente; una tesis, en definitiva, muy lejana de cualquier idea sobre capacidades dadas de antemano o sociedades estancadas en un " estadio » de evolución unilineal.

3. En este contexto parece significativo que una de las preocupaciones explicitas de Métraux (1934, p. 181) haya sido evaluar la pertinencia de la tesis de Paul Rivet: « el problema de la existencia o inexistencia de un substractum arawak en la región andina $"$.

4. El título de esa obra era La religión y las representaciones misticas de los indios cuna. Este cambio final de intereses no podia carecer de significación para Métraux (1932b, p. 236), cuyos análisis permanentemente pasaban de la cultura material a la espiritual, e incluso procuraban indagar las relaciones entre ambos ámbitos: «Él, cuyo interés estaba puesto casi exclusivamente en los aspectos materiales de las civilizaciones indígenas, a partir de su última expedición se habia lanzado al estudio de su vida psíquica, y de sus incursiones a este nuevo dominio había traído hechos de una importancia excepcional. Su libro sobre los cuna estaba destinado a sobrepasar los cuadros del americanismo y a aportar elementos de gran valor a la psicología y a la sociología religiosa en general ».

5. Según el competente biógrafo de Mauss, a través de los años éste siempre apoyó las candidaturas académicas de Métraux, a quien consideraba « uno de sus más brillantes alumnos » (Fournier 2005, 
p. 300). En cambio la relación con Paul Rivet, en la cual no profundizaremos aquí, fue más ambivalente y conflictiva. Ciertamente Rivet recomendó al joven Métraux para dirigir el Instituto de Etnología de Tucumán; de hecho, ocupaba una posición importante en la administración francesa de la época seleccionando etnógrafos francoparlantes (como Jacques Soustelle o Jehan Vellard) para destinarlos luego a posiciones estratégicas. Edgardo Krebs (2005) sugiere que, al menos en algunos casos, estos etnógrafos pudieron operar como agentes de inteligencia del gobierno francés.

6. Otro hecho que apoya la idea de una influencia fuerte de la sociología de la religión en esa época es que sabemos que entonces Métraux difundia los hallazgos de Mauss entre sus amistades: por ejemplo, introdujo al análisis de potlatch de Marcel Mauss a Georges Bataille (Fournier 2005, p. 284).

7. Para un ejemplo chiriguano, véase la serie de fotografias sobre el desarrollo del juego de tshúcareta (Nordenskiöld 2002, pp. 180-182).

8. En una carta de 1938 dirigida a Mauss, Métraux anota: « Me indigna escuchar en Francia juicios sobre la "falta de ideas" de los universitarios americanos. ¿Sabe usted que nadie puede graduarse sin conocer Las formas elementales, y sin haber leido al menos uno de sus artículos? » (Fournier 1994, pp. 634-635).

9. A propósito de las mismas, Wassén $(1932$, p. 239) escribió que «...un manual de etnografia sudamericana podría escribirse, en gran parte, con el material del museo ». En efecto, varios años después, esas colecciones proveerían alrededor del diez por ciento de las ilustraciones del monumental Handbook of South American Indians (Salomon y Skar 1987, p. 27).

10. En efecto, La Civilisation matérielle realiza esa comparación desde su primera línea: en cuanto a la extensión (Métraux 1928a, p. 7), en cuanto a su expansión migratoria (ibid., p. 293) y en cuanto a su capacidad inventiva (ibid., p. 310). La valoración privilegiada otorgada a ambas familias lingüísticas (tupí-guarani y arawak), que se suma a la valoración de los chiriguano, procede directamente de Nordenskiöld (1920, p. xiii): « Un asunto de particular interés en esta conexión es notar cómo dos pueblos que pertenecen a los más importantes grupos tribales de toda América realizaron adaptaciones en sus modos de vida cuando emigraron a lugares con condiciones naturales extrañas ".

11. Para una posibilidad renovada de postular la existencia de una unidad de los grupos tupiguarani desde una perspectiva cosmológica, véase por ejemplo la tesis de Viveiros de Castro (1992).

12. Métraux (1928a, p. 46) reconoce permanentemente esta deuda. Por citar algunos ejemplos: "Esta clasificación ha sido tomada de los mapas elaborados por el profesor Nordenskiöld, de quien he adoptado en buena medida el método ". O bien: "He establecido, con la ayuda de los mapas de Nordenskiöld y de los míos propios, una clasificación de todos los elementos de cultura » (ibid., p. 294).

13. Es el caso de la caracterización de ciertos personajes míticos como "lunares » o " solares ", siguiendo a Ehrenreich (Métraux 1928b, pp. 29, 42), que mantendría en escritos posteriores (Métraux 1932a, pp. 122-123). En algunas de sus primeras publicaciones, Métraux adhería a las teorías de Lévy-Bruhl sobre el pensamiento místico. Sin embargo esa influencia es casi imperceptible en sus escritos posteriores sobre mitología, y conviene no extenderla mucho más allá de una época estudiantil, ni mucho menos buscar en ella la clave de alguna de sus ideas posteriores - tal como hace Laurière (1996, pp. 27-28), quien afirma que dado este supuesto de dos tipos de mentalidad « irreductibles », los fenómenos híbridos como el cristianismo indígena provocaban en Métraux un " malestar explicativo ».

14. En términos similares eran traducidos los conceptos acuñados por los difusionistas alemanes: Kulturkreise, así, era " ảreas de civilización », y Kulturschichten « lecho de civilización ».

15. Hay que observar que, al menos en los escritos tempranos sobre los chiriguano y los pueblos chaqueños, Métraux utilizaba la palabra « civilización »en varios sentidos, que dependian del contexto y la amplitud del estudio en cuestión. De este modo, si en sus escritos comparativos la palabra responde cabalmente a la definición de Durkheim y Mauss, en los estudios localizados usaba "civilización " como sinónimo de "cultura », y solía utilizar la palabra "civilizado » con un matiz ciertamente evolucionista ( escala de civilizaciones »), que otras veces giraba hacia un uso irónico para denotar la idea de " aculturado ».

16. Esta transformación, sin embargo, no comprometía la inclusión del grupo en la familia tupí-guaraní, ni menos aún la unidad de esta última: «En efecto, los tupi-guaraní que poseen una 
civilización más evolucionada, como los chiriguano o los omagua, hablan un dialecto del guaraní muy puro, mientras que los mundurukú, los apiaká y los mauhé, cuya lengua es la más diferenciada, han conservado en cambio buena parte de la cultura material común a la mayoría de las otras tribus y en particular a los tupinambá » (Métraux 1928a, p. 281). Una vez más, la idea respondía a una de las reglas de difusión enunciadas por Nordenskiöld (1929, p. 22): « Si, en el nuevo habitat, la tribu entra en contacto con una población que ella misma ha debido adaptarse a las condiciones locales [...], es natural que a su vez esta tribu tome mucho de sus nuevos vecinos. Su cultura material va, desde entonces, a ofrecer una mezcla de sus antiguos usos y de aquellos que encontrará entre las tribus del nuevo territorio. [...] Las tribus de origen diferente, que viven juntas e intercambian su cultura bajo las mismas condiciones naturales, por lo común alcanzan una civilización homogénea ».

17. Asimismo, la revista que fundó Métraux debía transformarse para el universo americanista en lo que la Anthropos de Wilhelm Schmidt era entonces para Europa (Métraux 1932c).

18. Patricia Arenas (2003, pp. 129-130) deplora en Métraux la falta de sugerencias de " medidas humanas para modificar la situación social de los aborígenes, aparte de una fría anotación al margen "; considera que esa " operación de rescate " posee un " sesgo arqueológico, como si se tratase de relictos en riesgo de disolverse ", y que el "salvataje » se reducía a la " publicación de monografias producto del trabajo de campo ». Sugiere, además, que esa supuesta actitud pasiva de Métraux suponía « hacer invisibles " las « nuevas relaciones sociales capitalistas ", la « irrupción del control administrativo de representantes del Estado-nación argentino " y la acción sobre los indígenas de los «propietarios y administradores de los ingenios del noroeste argentino " - quienes, nos recuerda, financiaron el Instituto y el Museo de Tucumán. Todo esto parece discutible. Considerando apenas el caso chiriguano, respecto del primer punto podemos mencionar las advertencias de Métraux (1931a, pp. 91-92) sobre las alteraciones que la comercialización producía en las industrias indigenas, o el trauma que el trabajo asalariado producía en su modo de vida en general. Respecto del segundo, si bien es cierto que dice poco acerca de la presencia militar argentina en la región, pueden recordarse sus denuncias sobre la politica boliviana de «destruir o eliminar » a los chiriguano (ibid., p. 107), o sobre el perjuicio que les causaría la secularización de las misiones - a sus ojos, ciertamente, un "mal menor» (Métraux 1929b, 1929d, 1933a, 1933b). Finalmente, respecto del tercer punto, la impugnación es tan flagrante que la misma Arenas (2003, p. 129) se ve forzada a reconocer que «Métraux señala a los agentes del cambio como los colonos blancos de los ingenios y autoridades locales ». En resumen, estos procesos supuestamente « invisibles " - si bien no conforman objetos de estudio explícito - aparecen recurrentemente en los escritos de Métraux, y del mismo modo sus múltiples denuncias de maltratos e injusticias no concuerdan con esa actitud distante o pasiva que se le imputa. Como aquí intentamos demostrar, Métraux efectivamente adhería a un método de análisis que lo aproximaba a la arqueología y privilegiaba el rescate de los rasgos que en su óptica no se deben a la aculturación; por otra parte, poseía compromisos institucionales que le imponian la reunión de colecciones. Pero no parece justificado caracterizar esta perspectiva teórico-metodológica como una matriz perceptiva - o peor, una actitud ideológica o personal - que invisibilizaba determinados problemas sociales.

19. Nordenskiöld $(1929$, p. 24), en cambio, no se resistia a examinar la aculturación chiriguano como un proceso de difusión que respondia a las mismas reglas que operaban en los contactos entre grupos indigenas: « Es así que los chiriguano están muy orgullosos de vestirse como blancos, y de que sus mujeres se hagan orificios en las orejas para colgar los anillos que llevan las mujeres blancas. [...] Por otro lado, los chiriguano jamás habian tenido la idea de imitar a las tribus menos civilizadas del Chaco. Es de presumir que los indios de las tribus que viven al Este de los Andes han imitado del mismo modo a los incas o a los indios del mismo nivel de cultura con los cuales se hallaban en contacto. Por todas partes, a través del Chaco, son ante todo los jefes y los intérpretes quienes se visten al modo de los blancos. Este atuendo es considerado como elegante ».

20. Para un resumen de esta extensa polémica, véase De Gandia (1935, pp. 44-52).

21. Es interesante comparar esta forma de pesimismo, que anunciaba una degeneración progresiva de la técnica alfarera, con el manifestado por Nordenskiöld (2002, p. 223), veinte años antes, negando 
un proceso de esta índole: « Con seguridad, cuanto más se "civiliza" a los indios menos logran en el ámbito artesanal. De los blancos no aprenden mucho más que la preparación del aguardiente y el beber. En la medida en que el contacto entre los indios y los blancos está aumentando, la artesanía indígena está desapareciendo paulatinamente, pero no se está transformando. Gran parte de ella se mantiene enteramente indigena hasta que finalmente cae en el ocaso ».

22. El hecho también había sido constatado por Nordenskiöld (1920, p. 139): «Algunos tipos son locales y por eso característicos de ciertos poblados; otros son ciertamente individuales. Así, he visto diferentes mujeres en el mismo poblado producir cántaros diferentes. Algunas mujeres son famosas por realizar trabajos especialmente finos. Son celebradas por su cerámica mucho más allá de su propio poblado ».

23. « Siempre, en cualquiera de sus productos, se nota el buen gusto, sentido del cual se hallan muy desprovistos los colonos blancos » (Métraux 1929a, p. 2).

24. La existencia en las comunidades indígenas, o al menos lejos de las ciudades, atraía y repugnaba a Métraux al mismo tiempo. En las más remotas páginas de su diario encontramos varios pasajes que muestran vívidamente otro perfil de esa «nostalgia ». El « ritmo más lento » de la vida social, que confesaba haber experimentado en el Chaco y que con los años comenzó a añorar, recibía entonces una expresión mucho más cruda. Tomemos un ejemplo, anotado en la misión wichí de San Andrés: « El aburrimiento a veces deviene una tentación; uno se siente confortable en él como en una cama [...]. Estoy contento de abandonar la misión, pero un poco asustado de volver al "mundo". En mi neurastenia me siento cobijado, protegido en este confinamiento como en la Isla de Pascua, como en Honolulu » (Métraux 1978, p. 89). Encontramos la misma idea en un memorable pasaje de una carta enviada a Michel Leiris: « La soledad me ha corrompido para siempre: no podría existir mucho tiempo lejos de ella [...]. Tal vez tengo el corazón tímido y un miedo terrible a la vida. Reacciono a este miedo por medios mecánicos: exceso de erudición, viajes lejanos, siempre barreras entre yo y el exterior. Si alguna vez me convierto en un gran sabio, será por miedo » (citado en Poitry 1996, p. 8).

25. Así, resulta intrigante que en su posterior viaje por la región, en 1939, Métraux no haya visitado ni siquiera de paso a los chiriguano. Más todavía si consideramos que algunas de sus comunidades se habian formado tras el éxodo provocado por la Guerra del Chaco, que como todo movimiento migratorio interesaba vivamente a Métraux (1934, p. 183): « Me represento la migración de los Guaranís del Paraguay hacia el pie de los Andes, en la actual república boliviana, como un fenómeno algo parecido, en escala mayor por supuesto, al que se produce en la actualidad en el noroeste de la Argentina ».

26. Por otro lado, es justo reconocer que estas categorías concordaban con las percepciones interétnicas de los propios chiriguano y chané: « Jamás una mujer chiriguana contraerá enlace con un toba $\mathrm{u}$ otro indio chaqueño: sería para ella una deshonra inaudita tener relaciones con gente que los chiriguano califican desdeñosamente de "indios" " (Métraux 1935, p. 421).

27. Sugestivamente, Nordenskiöld (2002, p. 155) asocia esta asimetría con el hecho de que la sociedad blanca mantiene los topónimos de las « altas culturas» (como los guaraní « Charagua » y " Carandaiti ») pero jamás los de « culturas inferiores » como los chorote o los mataco.

28. Las virtudes comparativas de los chiriguano tampoco habían pasado inadvertidas para Nordenskiöld (1920, p. xii): « Un estudio detenido de la civilización chiriguano y chané, usando el método etno-geográfico, ofrece puntos de interés especial, ya que su modo de vida es bastante conocido, y podemos rastrear su historia hasta los comienzos del siglo XVI 》.

29. Métraux (1931d, p. 101), por ejemplo, confiesa que la supuesta ignorancia de los chiriguano para construir vallas o trincheras siempre lo había sorprendido, puesto que sus parientes del Paraguay dominaban esa tan provechosa técnica bélica. Esta dudosa negligencia ponía en cuestión una filiación tan directa entre ambos grupos; por lo tanto, cuando descubrió en la crónica del Padre de Mora que este grupo, efectivamente, también conocía esa costumbre, tan sólo confirmó lo que su estudio etno-geográfico de la familia tupí-guaraní lo había inducido a suponer.

30. A la abundancia de crónicas históricas se agregaban otras razones. Como hemos dicho, los chiriguano y los chané se hallaban en la confluencia de tres de las mayores « áreas de civilización » de 
América del Sur: la tupi-guarani, la arawak y la andina. Las discusiones generales sobre las influencias recíprocas entre estos grupos, pues, encontraban en este caso una suerte de modelo a escala de los grandes procesos ocurridos durante siglos en todo el continente.

31. Véase también De Gandia (1929, pp. 163-180). Métraux (1928a, p. 291) llegó a atribuir un carácter claramente pionero a esa aventura: « Fue la señal de una gran invasión cuyo resultado fue el establecimiento al pie de los Andes de una cantidad de guarani que se conocieron desde entonces bajo el nombre de chiriguano $"$.

32. Por ejemplo: « Es lamentable que Frazer no haya podido conocer los hechos que me propongo citar, y que le habrian demostrado la existencia incontestable de hombres-dioses entre las tribus primitivas de América tropical. Al menos tuvo la intuición de ello, gracias a un texto de Thevet [...]. Esta evolución que Frazer presagia [que eleva al mago al rango de "rey divino"] ya había tenido lugar antes de la conquista " (Métraux 1931c, pp. 63-64). Es preciso notar que esos párrafos-y con ellos cualquier mención a Frazer - fueron suprimidos en la reedición del mismo artículo, planeada por Métraux poco antes de su muerte, en Religión y magias indigenas de América del Sur (1973).

33. Veamos un ejemplo: «Cuando una de esas palabras onomatopéyicas para el ave posee una distribución tal que forma un área ininterrumpida, podemos presumir que ha surgido en un sitio y subsecuentemente se ha expandido, junto con las aves, de tribu en tribu " (Nordenskiöld 1922, p. 13).

34. A veces, las comparaciones mitológicas iban mucho más lejos. Métraux llegó a detectar semejanzas sorprendentes entre la mitología de los grupos chaqueños y la de los indios de las planicies norteamericanas, sugiriendo incluso que las mismas senalaban la posible existencia de una « cultura muy arcaica » común a todos ellos. Pero nunca desarrolló esta idea in extenso. El proyecto estructuralista retomaría con agrado muchas de estas intuiciones (Lévi-Strauss 1986, p. 54; 1992, pp. 80-104).

35. Carta a Robert Lowie del 31 de mayo de 1933 (Robert Lowie Papers, BANC MSS C-B 927 , Series 1, Correspondence. The Bancroft Library, University of California Berkeley).

36. Tal como sugiere Matthey (1996, p. 32), es esta concepción de la etnologia, contrapuesta con demasiadas corrientes actuales de la antropologia, la que explica la perennidad de la obra de Métraux: « Hoy existen antropólogos que escriben sobre el postmodernismo y la hermenéutica conjetural. Podemos preguntarnos si sus obras resistirán la usura del tiempo, el más implacable e imparcial de los jueces. Las obras de Métraux son una fuente de la cual podemos siempre sacar provecho ".

\section{REFERENCIAS BIBLIOGRÁFICAS CITADAS}

\section{Alvarsson Jan-Åke}

1982 "Colección etnográfica del Gran Chaco boliviano nos recuerda del finado etnógrafo sueco, ex-director del Museo Etnográfico de Gotemburgo, Suecia ", Göteborgs Etnografiska Museum Årstryck, 1979-1980, Motala, pp. 1520.

\section{Arenas Patricia}

2003 «Alfred Métraux y su visión del mundo indígena en los trabajos etnográficos en el Chaco argentino ", Bulletin de la Société suisse des Américanistes, 66-67, pp. 127-132.

\section{BaLdus Herbert}

1963 "Métraux e la etnologia brasileira », Revista del Museo Paulista, XIV, pp. 45-59.

Bing Fernande

1964 «Entretiens avec Alfred Métraux », L’Homme, 4 (2), pp. 20-32. 
BOMAN Éric

1905 "Migrations précolombiennes dans le Nord-Ouest de l'Argentine », Journal de la Société des Américanistes, 2 (1), pp. 91-108.

1908 Antiquités de la région andine de la république d'Argentine et du désert d'Atacama (tomo I), Imprimerie nationale, París, pp. 255-318.

Braunstein José

1978 "Bosquejo de una historia social de los chiriguano (tupí-guaraní) », Cuadernos Franciscanos, 49, pp. 111-132.

César José Vicente

1966 «Enterros em urnas dos Tupi-Guarani », Revista de Antropologia, 14, pp. 64-71.

Comikès Isabelle y Thierry SAIGNES

1994 "Chiriguano: nacimiento de una identidad mestiza », in Jürgen Riester (ed.), Chiriguano, APCOB, Santa Cruz, pp. 25-221.

Debenedetti Salvador

1910 Exploración arqueológica en los cementerios prehistóricos de la isla Tilcara (Quebrada de Humahuaca, Provincia de Jujuy), Imprenta J. A. Alsina, Buenos Aires.

1917 Investigaciones arqueológicas en los valles preandinos de la Provincia de San Juan, Ministerio de Agricultura de la Nación, Buenos Aires.

De Gandía Enrique

1929 Historia critica de los mitos de la conquista americana, Ed. Juan Roldán y Compañía, Buenos Aires/Madrid.

1935 Historia de Santa Cruz de la Sierra. Una nueva república en Sud América, Talleres Gráficos Argentinos de L. J. Rosso, Buenos Aires.

DuRKheim Émile

1995 Las formas elementales de la vida religiosa, Diálogo Abierto, México [1912].

DURKheis Émile y Marcel Mauss

1969 « Note sur la notion de civilisation », in Émile Durkheim, Journal Sociologique, Presses universitaires de France, París, pp. 681-684.

FERNÁNDEZ Jorge

2003 "En el centenario de la expedición sueca de 1901-1902 al Chaco y cordilleras : cuantificación, puesta en valor y análisis de sus resultados ", Pacarina, 3 , pp. 17-27.

FOURNIER Marcel

$1994 \quad$ Marcel Mauss, Fayard, París.

2005 Marcel Mauss. A biography, Princeton University Press, Princeton/Oxford.

Giobellina Brumana Fernando

2005 Soñando con los dogon. En los origenes de la etnografia francesa, Consejo Superior de Investigaciones Cientificas, Madrid.

Krebs Edgardo

2005 "Alfred Métraux and the Handbook of South American Indians. A view from within ", History of Anthropology Newsletter, 32 (1), pp. 3-11. 
LAURIÈRE Christine

1996 "Alfred Métraux, un ethnographe sur les marches de la civilisation », Bulletin du Centre Genevois d'Anthropologie, 5, pp. 21-29.

Lévi-Strauss Claude

1964 "Hommage à Alfred Métraux », L’Homme, 4 (2), pp. 5-8.

1986 La alfarera celosa, Paidós, Barcelona.

1992 Historia de lince, Anagrama, Barcelona.

LowIE Robert

1933 «Erland Nordenskiöld », American Anthropologist, 35, pp. 159-169.

1974 Historia de la etnología, Fondo de Cultura Económica, México.

MALINOWSKI Bronislaw

1926 Crime and custom in savage society, Kegan Paul, Trench \& Trubner, London.

Matthey Piero

1996 «Le terrain, mon amour », Bulletin du Centre Genevois d'Anthropologie, 5, pp. 31-35.

Mauss Marcel

1974a Oeuvres 2. Représentations collectives et diversité des civilisations, Éditions de Minuit, París.

1974b Introducción a la etnografia, Istmo, Madrid.

Métraux Alfred

1928a La civilisation matérielle des tribus Tupi-Guarani, Paul Geuthner, París.

1928b La Religion des Tupinambas et ses rapports avec celle des autres tribus Tupi-Guarani, Librairie Ernest Leroux, París.

1929a «La alfarería de los indios chiriguano », Ensayos, 1 (2), pp. 1-3.

1929b «Plan acerca de la creación de un museo etnográfico en la Provincia de Tucumán », Boletin de la Universidad de Tucumán, 35, pp. 1-3.

1929c "Una civilización que muere », La Prensa (15/12/1929, 2 sección), Buenos Aires.

1929d "La sécularisation des missions franciscaines du Chaco bolivien ", Journal de la Société des Américanistes, 21 (2), pp. 420-422.

1930a "Études sur la civilisation des indiens chiriguano », Revista del Instituto de Etnología de la Universidad de Tucumán, I, pp. 295-493.

1930b "Expedición arqueológica a la Candelaria (Provincia de Salta) », Journal de la Société des Américanistes, 22 (2), pp. 402-404.

1931a "Observaciones sobre psicología de los indios Chiriguanos », Solar, 1, pp. 89-122.

1931b «La mujer en las sociedades primitivas », Azul, 2 (10), pp. 120-139.

1931c "Les hommes-dieux chez les Chiriguano et dans l'Amérique du Sud», Revista del Instituto de Etnología de la Universidad Nacional de Tucumán, II (1), pp. 61-91.

1931d «Introducción » a « Relación y breve noticia de lo sucedido en la guerra de los chiriguano » (P. Bartholomé de Mora), Revista del Instituto de Etnología de la Universidad Nacional de Tucumán, II (1), pp. 101-104. 
1932a "Mitos y cuentos de los indios chiriguano », Revista del Museo de La Plata, 33 (9), pp. 119-184.

1932b «Introduction a H. Wassén. Le Musée ethnographique de Göteborg et l'œuvre d'Erland Nordenskiöld ", Revista del Instituto de Etnología de la Universidad Nacional de Tucumán, II (2), pp. 233-237.

1932c "El Instituto de Etnología de la Universidad de Tucumán », La Nación (9/7/1932), 4 sección, Buenos Aires, p. 9.

1932d "La mujer chiriguana », La Gaceta (4/8/1932), sección literaria, Tucumán.

1933a "La obra de las misiones inglesas en el Chaco », Journal de la Société des Américanistes, 25 (1), pp. 205-209.

1933b "Nouvelles de la mission A. Métraux », Journal de la Société des Américanistes, 25 (1), pp. 203-205.

1934 «El estado actual de nuestros conocimientos sobre la extensión primitiva de la influencia guaraní y arawak en el continente sudamericano ", Actas y trabajos cientificos del $25^{\circ}$ Congreso Internacional de Americanistas (La Plata 1932), vol. I, Buenos Aires, pp. 181-190.

1935 "La mujer en la vida social y religiosa de los indios Chiriguano ", Revista del Instituto de etnología de la Universidad de Tucumán, 3, pp. 416-430.

1943a "The Social Organization and Religion of the Mojo and Manasi », Primitive Man. Quarterly, Bulletin of the Catholic Anthropological Conference, XVI (1-2), pp. 1-30.

1943b "Suicide Among the Matako of the Argentine Gran Chaco », América Indigena, III (3), pp. 199-209.

1946a "Ethnography of the Gran Chaco », in Julian H. Steward (ed.), Handbook of South American Indians, vol. 1, Smithsonian Institution, Washington, pp. 197-370.

1946b Myths of the Toba and Pilagá Indians of the Gran Chaco, American Folklore Society, Filadelfia.

1948a "Tribes of the Eastern Slopes of the Bolivian Andes. Chiriguano and Chané ", in Julian H. Steward (ed.), Handbook of South American Indians, vol. 3, Smithsonian Institution, Washington, pp. 465-485.

1948b "The guarani », in Julian H. Steward (ed.), Handbook of South American Indians, vol. 3, Smithsonian Institution, Washington, pp. 69-94.

1953 "Alfredo Métraux », Humanitas, pp. 357-360.

1957 "Les messies de l'Amérique du Sud », Archives de Sociologie des Religions, 4, pp. 108-112.

1973 Religión y magias indigenas de América del Sur, Aguilar, Madrid.

1978 Itinéraires 1. Carnets de notes et journaux de voyage, Payot, París.

\section{NORDENSKIÖLD Erland}

1917 "The Guaraní invasion of the Inca empire in the Sixteenth Century: an historical Indian migration ", Geographical Review, 4 (2), pp. 103-121.

1920 The changes in the material culture of two indian tribes under the influence of new sourroundings, Elanders Boktryckery Aktiebolag, Comparative ethnographical studies 2, Gotemburgo.

1922 Deductions suggested by the geographical distribution of some post-columbian words used by the indians of South America, Elanders Boktryckery Aktiebolag, Comparative ethnographical studies 5, Gotemburgo. 
1929 Analyse ethnogéographique de la culture matérielle de deux tribus indiennes du Gran Chaco, Les Éditions Genet, París.

2002 La vida de los indios. El Gran Chaco (Sudamérica), APCOB, La Paz.

Outes Félix E.

1909 "La cerámica chiriguana », Revista del Museo de La Plata, XVI (3), pp. 121-136.

PoItry Guy

1996 "Carrefour des poètes: Michel Leiris et Alfred Métraux », Bulletin du Centre Generois d'Anthropologie, 5, pp. 3-9.

\section{Rosen Eric von}

1924 Ethnographical Research Work during the Swedish Chaco-Cordillera Expedition 1901-1902, C. E. Fritze Ltd., Estocolmo.

\section{SAIGNES Thierry}

1984 «L'ethnographie missionaire des sauvages. La première description franciscaine des Chiriguano (1782) », Journal de la Société des Américanistes, 70, pp. 21-42.

1990 Ava y Karai. Ensayos sobre la frontera chiriguano (siglo xyl-xx), Hisbol, La Paz.

SALOMON Frank y Harald SKaR

1987 "Introduction », in Frank Salomon y Harald Skar (eds), Natives and Neighbours in South America. Anthropological Essays, Göteborgs Etnografiska Museum, Etnologiska Studier 38, Gotemburgo, pp. 13-44.

\section{STOCKING George W.}

1995 After Tylor: British Social Anthropology 1888-1951, The University of Wisconsin Press, Madison.

SUSNIK Branislava

1968 Chiriguanos I. Dimensiones etnosociales, Museo Etnográfico Andrés Barbero, Asunción.

\section{Viveiros de Castro Eduardo}

1992 From the enemy's point of view. Humanity and divinity in an Amazonian society, The University of Chicago Press, Chicago.

Wassén Henry

1932 «Le Musée ethnographique de Göteborg et l'œuvre d'Erland Nordenskiöld », Revista del Instituto de Etnología de la Universidad Nacional de Tucumán, II, pp. 237-262.

1990 «Studies and museum work for Erland Nordenskiöld during the years 1929 to 1932. His last student looks back over more than half a Century ", Göteborgs Etnografiska Museum Årstryck, 1987-1988, Gotemburgo, pp. 3544. 


\section{BIBLIOGRAFÍA COMPLEMENTARIA}

BOSSERT Federico

2005 Compte rendu de « Monnier Alain, éd., Nostalgie du Néolithique : de Lausanne à Las Lomitas. Documents sur Alfred Métraux, ethnologue, Labor et Fides/Société d'études Alfred Métraux, Genève, 2003 », Journal de la Société des Américanistes, 91 (2), pp. 224-228.

\section{MÉTraux Alfred}

1927 "Les migrations historiques des Tupi-Guarani », Journal de la Société des Américanistes, 19, pp. 1-45.

1929 "L'origine religieuse du jeu du mboto chez les Chiriguano », Journal de la Société des Américanistes, 21 (2), pp. 422-423.

1929 "Découverte d'objets péruviens sur le moyen Pilcomayo », Journal de la Société des Américanistes, 21 (2), pp. 423-424.

1929 "Le souvenir d'Erland Nordenskiöld dans le Chaco », Journal de la Société des Américanistes, 21 (2), pp. 436-437.

MuÑoz Adriana

2003 «Colecciones y coleccionistas. Una aproximación histórica a la formación de colecciones arqueológicas sudamericanas durante 1913-1932 en Gotemburgo, Suecia », Pacarina, 3, pp. 241-249.

NORDENSKIÖLD Erland

1902 «Explorations dans la région frontière entre la République Argentine et la Bolivie ", Bulletin de la Société de Geographie, VI, pp. 75-78.

NúÑez RegueIro Víctor A. y Marta A. TARTusı

2003 «Los arqueólogos suecos en Argentina, noventa años después: el convenio entre la Universidad Nacional de Tucumán y la Universidad de Gotemburgo (Suecia) ", Pacarina, 3, pp. 251-262.

Outes Félix E.

1907 «Alfarerías del noroeste argentino », Anales del Museo de La Plata, I, pp. 5-52.

Perez Ouriel y Éric NAVET

2003 " L'anthropophagie des Tupi-Guarani: du sujet bon à penser à l'objet bon à manger », Bulletin de la Société suisse des Américanistes, 66-67, pp. 101-112.

Rivet Paul

1933 "L'Institut d'ethnologie de l'université de Tucumán », Journal de la Société des Américanistes, 25, pp. 188-189. 